\title{
Wiring Specificity and Synaptic Diversity in the Mouse Lateral Central Amygdala
}

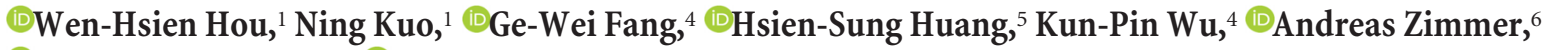 \\ 이en-Kun Cheng, ${ }^{7,8}$ and ${ }^{-C}$ Cheng-Chang Lien ${ }^{1,2,3}$ \\ ${ }^{1}$ Institute of Neuroscience, ${ }^{2}$ Institute of Brain Science, ${ }^{3}$ Brain Research Center, and ${ }^{4}$ Institute of Biomedical Informatics, National Yang-Ming University, \\ Taipei 112, Taiwan, ${ }^{5}$ Graduate Institute of Brain and Mind Sciences, College of Medicine, National Taiwan University, Taipei 100, Taiwan, ${ }^{6}$ Institute of \\ Molecular Psychiatry, Medical Faculty, University of Bonn, 53127 Bonn, Germany, ${ }^{7}$ Department of Medicine, MacKay Medical College, New Taipei City 252, \\ Taiwan, and ${ }^{8}$ Department of Anesthesiology, MacKay Memorial Hospital, Taipei 104, Taiwan
}

The central amygdala (CeA) nucleus, a subcortical structure composed of mostly GABA-releasing (GABAergic) neurons, controls fear expression via projections to downstream targets in the hypothalamus and brainstem. The CeA consists of the lateral (CeL) and medial (CeM) subdivisions. The CeL strongly gates information transfer to the CeM, the main output station of the amygdala, but little is known about the functional organization of local circuits in this region. Using cluster analysis, we identified two major electrophysiologically distinct CeL neuron classes in mouse amygdala slices, the early-spiking (ES) and late-spiking (LS) neurons. These two classes displayed distinct autaptic transmission. Compared with LS neurons, ES neurons had strong and depressing autapses, which enhanced spiketiming precision. With multiple patch-clamp recordings, we found that CeL neurons made chemical, but not electrical, synapses. Analysis of individual connections revealed cannabinoid type 1 receptor-mediated suppression of the ES, but not of the LS cell output synapse. More interestingly, the efficacy of the ES $\rightarrow$ LS or LS $\rightarrow$ ES synapse was $\sim 2$-fold greater than that of the LS $\rightarrow$ LS or ES $\rightarrow$ ES synapse. When tested at $20 \mathrm{~Hz}$, synapses between different neurons, but not within the same class, were markedly depressing and were more powerful to sculpt activity of postsynaptic neurons. Moreover, neurons of different classes also form synapses with higher degree of connectivity. We demonstrate that ES and LS neurons represent two functionally distinct cell classes in the CeL and interactions between presynaptic and postsynaptic neurons dictate synaptic properties between neurons.

Key words: autapse; connectivity; depression; facilitation; short-term plasticity; synapse specificity

Significance Statement

The central lateral amygdala $(\mathrm{CeL})$ is a key node in fear circuits, but the functional organization of local circuits in this region is largely unknown. The CeL consists of mostly GABAergic inhibitory neurons with different functional and molecular features. Here, we report that the presynaptic cell class determines functional properties of autapses and cannabinoid-mediated modulation of synaptic transmission between neurons, whereas presynaptic versus postsynaptic cell classes dictate the connectivity, efficacy, and dynamics of GABAergic synapses between any two neurons. The wiring specificity and synaptic diversity have a great impact on neuronal output in amygdala inhibitory networks. Such synaptic organizing principles advance our understanding of the significance of physiologically defined neuronal phenotypes in amygdala inhibitory networks.

\section{Introduction}

The amygdala plays an important role in associative fear learning (LeDoux, 2007; Ehrlich et al., 2009; Johansen et al., 2011). A classical form of this learning is fear conditioning, in which animals learn to associate a neutral conditioned stimulus with an aversive unconditioned stimulus (for review, see Maren, 2001; Johansen et al., 2011). Both conditioned stimulus and uncondi-

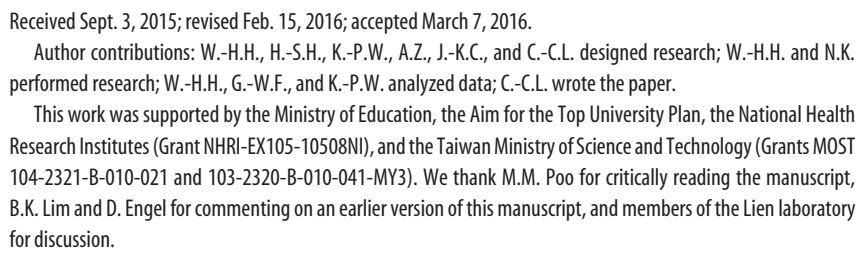
104-2321-B-010-021 and 103-2320-B-010-041-MY3). We thank M.M. Poo for critically reading the manuscript, B.K. Lim and D. Engel for commenting on an earlier version of this manuscript, and members of the Lien laboratory for discussion.

\section{The authors declare no competing financial interests.}

Correspondence should be addressed to either of the following: Jen-Kun Cheng, Department of Anesthesiology, MacKay Memorial Hospital, №. 92, Sec. 2, Zhongshan N. Rd., Taipei 10449, Taiwan, E-mail: jkcheng@usa.net; or Cheng-Chang Lien, Institute of Neuroscience, National Yang-Ming University, 155, Section 2, Li-Nong Street, Taipei 112, Taiwan, E-mail: cclien@ym.edu.tw.

D0I:10.1523/JNEUROSCI.3309-15.2016

Copyright $\odot 2016$ the authors $\quad 0270-6474 / 16 / 364549-15 \$ 15.00 / 0$ 
tioned stimulus inputs converge to the lateral amygdala (LA), which then projects to the central amygdala $(\mathrm{CeA})$ through direct and indirect connections in other amygdala regions (Pitkänen et al., 1997; Amano et al., 2010; Johansen et al., 2011). The CeA comprises the lateral (CeL) and medial (CeM) subdivisions. CeL neurons project onto the downstream CeM "output" neurons, which finally drive the expression of conditioned fear responses via projections to the brainstem and hypothalamus (Viviani et al., 2011). Therefore, the CeL is a relay station between the amygdala complex and downstream fear effectors (Paré et al., 2004; Sigurdsson et al., 2007; Johansen et al., 2011).

A number of recent studies shed new light on the CeL undertaking an active role in the acquisition, consolidation, and extinction of conditioned fear (Wilensky et al., 2006; Ehrlich et al., 2009; Ciocchi et al., 2010; Pare and Duvarci, 2012; Li et al., 2013). The CeL microcircuit consists of mostly GABA-releasing (GABAergic) inhibitory neurons with different functional and molecular features (Cassell et al., 1999; Martina et al., 1999; Lopez de Armentia and Sah, 2004; Ciocchi et al., 2010; Haubensak et al., 2010; Amano et al., 2012; Li et al., 2013). By making reciprocal inhibitory connections, these neurons provide both feedforward and/or feedback inhibition within the CeL (Ciocchi et al., 2010; Haubensak et al., 2010; Li et al., 2013). Recent optogenetic approaches have demonstrated that intra-CeL inhibition gates $\mathrm{CeL}$ output and therefore controls the function of CeM and the expression of fear (Ciocchi et al., 2010; Haubensak et al., 2010; Pare and Duvarci, 2012). The CeL contains diverse GABAergic neuron classes, but the synaptic organization of local inhibitory circuits in this region is largely unknown.

Here, we performed multiple whole-cell patch-clamp recordings from CeL neurons in mouse slices and investigated their synaptic connections. We found that two major classes of CeL neurons with distinct firing patterns, namely the early-spiking (ES) and the late-spiking (LS) neurons, form two functionally distinct types of autapses. The efficacy of autaptic transmission in ES neurons was greater and was able to enhance spike-timing precision. Furthermore, brief depolarization of postsynaptic cells rapidly induced cannabinoid type 1 receptor $\left(\mathrm{CB}_{1} \mathrm{R}\right)$-mediated suppression of output synapses of the presynaptic ES cells, but not the LS cells. Although CeL neurons are mutually connected, they prefer to form synapses with the different class. Intriguingly, presynaptic versus postsynaptic cell-type identities strongly dictate the efficacy and short-term plasticity (STP) of the CeL synapses. Synapses formed by different classes of cells are strong and markedly depressing when activated at $20 \mathrm{~Hz}$, whereas those between cells of the same class are weak and do not exhibit prominent facilitation or depression. Such cell-type-specific transmission, modulation, and connectivity are likely to be critical for amygdala network function.

\section{Materials and Methods}

Animals. Som-IRES-cre mice (Taniguchi et al., 2011) and the Ail4 reporter mice (Madisen et al., 2010) were purchased from the Jackson Laboratory. The $\mathrm{CB}_{1} \mathrm{R}$-knock-out $(\mathrm{KO})$ mice were derived from a stock of genotyped animals that were provided by Dr. Zimmer (Zimmer et al., 1999). All mice were bred onto the C57BL/6J genetic background. Male mice (at postnatal weeks 3-8) were used for all the experiments. Animal procedures were performed in accordance with the National Institutes of Health's Guide for the Care and Use of Laboratory Animals. The experimental protocol was reviewed and approved by the Institutional Animal Care and Use Committee of National Yang-Ming University.

Electrophysiological slice recording. Animals were killed by rapid decapitation by appropriately trained researchers. In brief, their brains were rapidly removed and 300- to $350-\mu \mathrm{m}$-thick coronal sections were pre- pared with a vibratome (DTK-1000; Dosaka) using ice-cold sucrosebased solution containing the following (in $\mathrm{mm}$ ): $87 \mathrm{NaCl}, 25 \mathrm{NaHCO}_{3}$, $1.25 \mathrm{NaH}_{2} \mathrm{PO}_{4}, 2.5 \mathrm{KCl}, 10$ glucose, 75 sucrose, $0.5 \mathrm{CaCl}_{2}$, and $7 \mathrm{MgCl}_{2}$, bubbled with $95 \% \mathrm{O}_{2} / 5 \% \mathrm{CO}_{2}, \mathrm{pH}$ 7.4. Slices were then transferred to the same solution at $34^{\circ} \mathrm{C}$ for at least $30 \mathrm{~min}$ and allowed to cool naturally to room temperature. During experiments, slices were placed in a recording chamber and continuously superfused $(\sim 4 \mathrm{ml} / \mathrm{min})$ with oxygenated ACSF containing the following (in mM): $125 \mathrm{NaCl}, 25 \mathrm{NaHCO}_{3}, 1.25$ $\mathrm{NaH}_{2} \mathrm{PO}_{4}, 2.5 \mathrm{KCl}, 25$ glucose, $2 \mathrm{CaCl}_{2}$, and $1 \mathrm{MgCl}_{2}$. The CeL, which is delimited by bundles of axons, was identified with trans-illumination as described previously (Lopez de Armentia and Sah, 2004). Neurons in the CeL were then selected under visual control using infrared differential interference contrast (IR-DIC) videomicroscopy (Olympus BX51WI equipped with a charge-coupled device camera, DAGE IR-1000). To test the autaptic transmission, $20 \mathrm{~Hz}$ trains of five action potentials (APs) or depolarizing voltage steps were delivered to recorded cells. Paired or triple recordings were initiated by establishing a whole-cell recording from a CeL neuron and then testing its connectivity with as many as neighboring $\mathrm{CeL}$ neurons as possible within $100 \mu \mathrm{m}$ somatic distance. To test the electrical coupling between CeL neurons, 1 s current $(-50$ $\mathrm{pA}$ ) injections were delivered to one CeL neuron and the voltage responses were recorded simultaneously from the other cell. To induce the depolarization-induced suppression of inhibition (DSI), after $2 \mathrm{~min}$ baseline, the postsynaptic CeL neurons were depolarized to $0 \mathrm{mV}$ for $10 \mathrm{~s}$. Whole-cell patch-clamp recordings were made with a Multiclamp 700B amplifier (Molecular Devices). Recording electrodes (2-6 M $\Omega$ ) were pulled from borosilicate glass (outer diameter, $1.5 \mathrm{~mm} ; 0.32 \mathrm{~mm}$ wall thickness; Harvard Apparatus). Pipette capacitances of both electrodes were carefully compensated and series resistance was compensated using the automatic bridge balance (readouts after compensation were 6-18 $\mathrm{M} \Omega$ ). Signals were filtered at $4 \mathrm{kHz}$ except where noted using the 4-pole low-pass Bessel filter. A Digidata 1440A connected to a personal computer was used for stimulus generation and data acquisition. The sampling frequency was $10 \mathrm{kHz}$. Pulse sequences were generated by pCLAMP 10.2 or 10.3 (Molecular Devices). The recording temperature was $24 \pm$ $2^{\circ} \mathrm{C}$, except for a subset of STP experiments (see Fig. 8), in which it was $35 \pm 2^{\circ} \mathrm{C}$.

Solutions and drugs. The majority of whole-cell patch-clamp recordings were made with the intracellular solution containing the following (in mM): $144 \mathrm{KCl}, 0.2$ EGTA, 4 MgATP, 10 HEPES, $7 \mathrm{Na}_{2}$ phosphocreatine, $0.1 \mathrm{GTP}$, and $0.4 \%$ biocytin, $\mathrm{pH}$ adjusted to 7.3 with $\mathrm{KOH}$. For the experiments of investigating the inhibitory effect on neuronal output, we used a low $\mathrm{Cl}^{-}$internal solution containing the following (in mM): $136.8 \mathrm{~K}$-gluconate, $7.2 \mathrm{KCl}, 0.2 \mathrm{EGTA}, 4 \mathrm{MgATP}, 10 \mathrm{HEPES}$, $7 \mathrm{Na}_{2}$-phosphocreatine, $0.5 \mathrm{Na}_{3} \mathrm{GTP}$, pH 7.3 with $\mathrm{KOH}$, and $0.4 \%$ biocytin. In a subset of experiments, one or more of the following antagonists (Sigma-Aldrich unless otherwise indicated) was also added to the ACSF: 2 mM kynurenic acid to block AMPA and NMDA receptors; $1 \mu \mathrm{M}$ gabazine (Tocris Bioscience) to block $\mathrm{GABA}_{\mathrm{A}}$ receptors. $\mathrm{K}_{\mathrm{v}}$ channel blockers 4-amino-pyridine (4-AP; Sigma-Aldrich) and $\alpha$-dendrotoxin ( $\alpha$-DTX; Alomone Labs) were also applied in the presence of synaptic blockers (with additional $0.5 \%$ bovine serum albumin from UniRegion Bio-Tech for $\alpha$-DTX) via bath superfusion.

Hierarchical clustering analysis. To classify the cells, an unsupervised clustering analysis (Cauli et al., 2000; Jasnow et al., 2009; Sosulina et al., 2010) was performed by using squared Euclidean distances and Ward's method (Ward, 1963). Electrophysiological properties of CeL cells were tested for uniformity in their distributions. Each of the quantified 14 variables (listed in Table 1) was binned and tested by the D'AgostinoPearson normality test, which is based on the assumption that a variable is normally distributed in a class. Variables with a non-Gaussian distribution were used for subsequent unsupervised clustering. Hierarchical clustering arranges data items into a tree-like dendrogram in which tree leaves represent data items and the length of tree edges between leaves represents the dissimilarity between data items. Tree leaves belonging to a subtree suggest high similarity and therefore form a group. Hierarchical clustering operates as follows. First, each CeL neuron was transformed into a $4 \mathrm{D}$ data point with variables of spike delay, ramp ratio, resting membrane potential (RMP), and rheobase. Before clustering, we first 
Table 1. Electrophysiological properties of $L S$ versus ES cells in the CeL

\begin{tabular}{lccr}
\hline & LS (50) & ES (40) & $p$-value \\
\hline RMP (mV) & $-70.5 \pm 0.6$ & $-65.6 \pm 0.6$ & $<0.0001$ \\
Rheobase (pA) & $48.2 \pm 2.6$ & $34.3 \pm 2.9$ & 0.0005 \\
Spike delay (ms) & $1721 \pm 30$ & $712 \pm 70$ & $<0.0001$ \\
Ramp ratio & $1.28 \pm 0.02$ & $0.93 \pm 0.01$ & $<0.0001$ \\
Input resistance (MS) & $363 \pm 20$ & $406 \pm 24$ & 0.18 \\
Membrane time constant (ms) & $57.6 \pm 5.3$ & $57.2 \pm 6.3$ & 0.96 \\
First AP threshold (mV) & $-37.1 \pm 0.6$ & $-37.8 \pm 0.9$ & 0.47 \\
First AP max rising rate (V/s) & $232 \pm 10$ & $223 \pm 12$ & 0.65 \\
First AP max falling rate (V/s) & $43.6 \pm 1.4$ & $45.6 \pm 1.6$ & 0.37 \\
First AP half-width (ms) & $1.64 \pm 0.03$ & $1.53 \pm 0.06$ & 0.12 \\
First AP height (mV) & $88.0 \pm 1.3$ & $89.6 \pm 1.5$ & 0.41 \\
Second AP max rising rate (V/s) & $208 \pm 12$ & $195 \pm 18$ & 0.12 \\
Second AP max falling rate (V/s) & $44.3 \pm 2.5$ & $43.2 \pm 3.5$ & 0.32 \\
Second AP height (mV) & $79.9 \pm 1.2$ & $78.9 \pm 1.3$ & 0.97 \\
\hline
\end{tabular}

Wilcoxon rank-sum test was performed to determine statistical significance between the groups. Numbers of cells are given in parentheses. All values are given as mean \pm SEM.

normalized variables into the range $(0,1)$ by performing min-max normalization. The distance between data points represents the dissimilarity between them; closer data points have higher similarity. Next, we clustered all the data points by the following iterative procedure. First, assign each data point to a cluster; every cluster therefore contains only one data point. Second, merge the two closest clusters into one cluster; therefore, there is one cluster fewer than previously. Third, determine the distance between the new cluster and each of the old clusters. Fourth, repeat steps two and three until there is only one cluster left. Ward's method linkage rules (Ward, 1963), which minimizes the error sum of squares of any pair of cluster in step three. The pair of clusters with minimum betweencluster distance are merged. The hierarchical clustering analysis was performed with the Free Statistics Software (Office for Research Development and Education, version 1.1.23-r7, http://www.wessa.net/).

Sholl analysis. Sholl analysis (Sholl, 1953) was used to investigate dendritic complexity in relation to their distance from the soma. Briefly, concentric Sholl segments (concentric radial interval: $25 \mu \mathrm{m}$ ) were generated starting at a distance of $10 \mu \mathrm{m}$ from the center of the soma. The number of process intersections and dendritic length were analyzed per Sholl segment, respectively.

Recovery of biocytin-filled neurons. Neurons were filled with biocytin $(0.2-0.4 \%)$ during recordings. After $\sim 30 \mathrm{~min}$ of recording, slices were fixed overnight with $4 \%$ paraformaldehyde in phosphate-buffered solution (PB; $0.1 \mathrm{M}, \mathrm{pH} 7.3$ ). After washing with $\mathrm{PB}$, slices were incubated with FITC-conjugated avidin-D ( $2 \mu \mathrm{l} / \mathrm{ml}$; Invitrogen $)$ in $\mathrm{PB}$ containing $0.3 \%$ Triton X-100 overnight at $4^{\circ} \mathrm{C}$. After washing, slices were embedded in a mounting medium (Vectashield; Vector Laboratories).

Image acquisition and anatomical reconstruction. For 3D reconstruction of biocytin-labeled cells, high-resolution two-photon images of neurons were acquired. Labeled neurons were examined by a two-photon microscope using a pulsed titanium: sapphire laser (Chameleon-Ultra II tuned to $800 \mathrm{~nm}$; Coherent) attached to a Leica DM6000 CFS that was
A

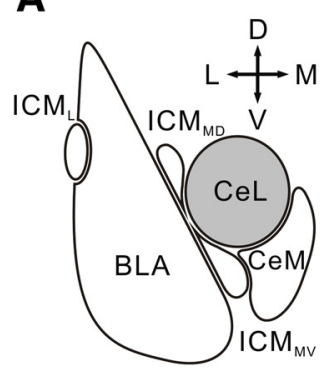

E

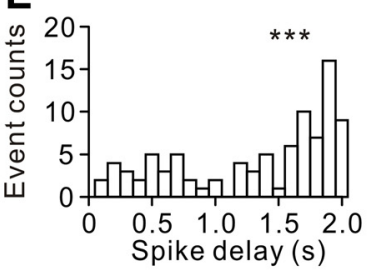

$\mathbf{F}$

o
B

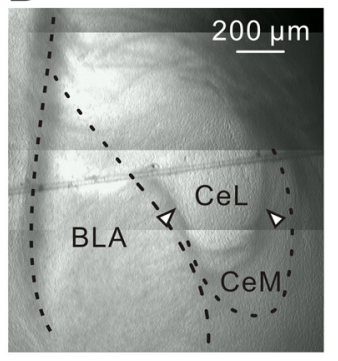

C

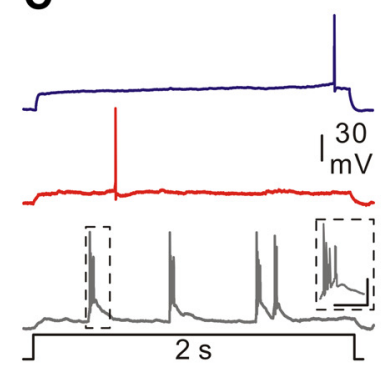

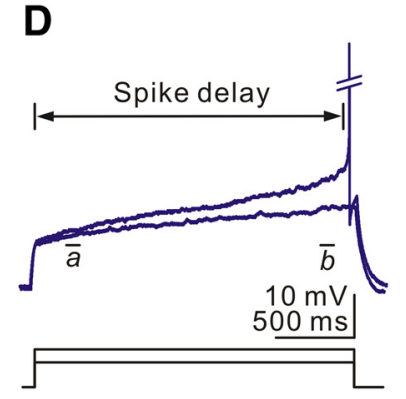

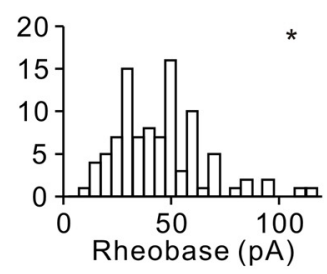

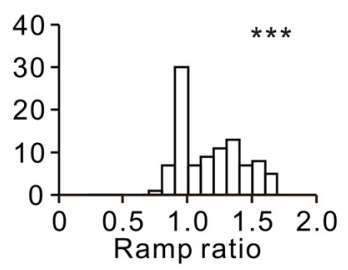

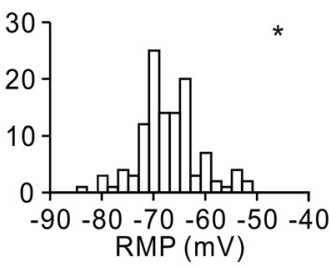

G
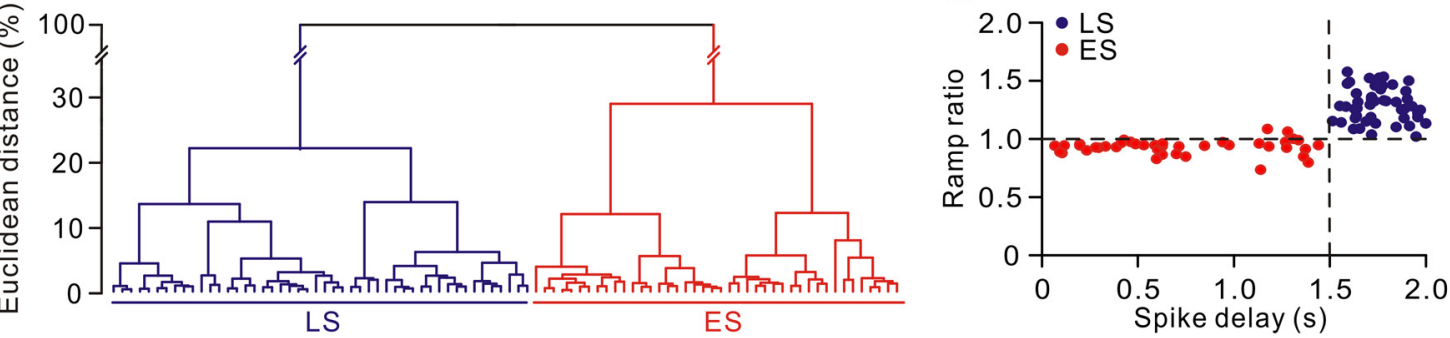

Figure 1. Heterogeneous intrinsic excitability of CeL neurons. $A$, Schematic drawing of the amygdala complex. Gray area denotes the recording area CeL. BLA, Basolateral amygdala; ICM, lateral

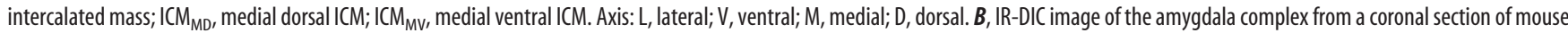
brain. White arrowheads indicate the axon bundles. The borders of CeL, CeM, and BLA are outlined. C, Exemplar firing patterns recorded from LS (top), ES (middle), and LTB (bottom) cells. Inset, Enlarged bursts (calibration: $15 \mathrm{~ms}, 30 \mathrm{mV}$ ). Notice that only $3.5 \%$ of recorded cells are LTB cells. $\boldsymbol{D}$, Representative membrane responses of an LS cell to the suprathreshold and subthreshold current injections. Note the slow depolarizing ramp. Bars $a$ and $b$ indicate how the average membrane potentials were measured for the calculation of ramp ratio (b/a). AP was truncated for display purposes. $E$, Histogram of spike delays, ramp ratios, RMPs, and rheobases from non-LTB cells. The $p$-values from the D'Agostino-Pearson omnibus normality test demonstrate that the properties presented are not unimodally distributed. Asterisks indicate significant deviation from a normal distribution $\left({ }^{*} p<0.05,{ }^{* *} p<0.01\right)$. $\boldsymbol{F}$, Hierarchical cluster analysis of non-LTB neurons performed with electrophysiological parameters shown in $\boldsymbol{E}$ as the parameters for classification. The $x$-axis of the dendrogram represents the individual cells and the $y$-axis represents the rescaled distance (squared Euclidean) between groups. Distinct types of neurons are marked with bars below the dendrogram. G, Scatterplot of spike delay versus ramp ratio. Cells classified as $L S$ and ES phenotypes in the dendrogram are blue and red, respectively. The dotted lines indicate the arbitrary cutoff values (spike delay of $1.5 \mathrm{~s}$; ramp ratio of 1.0) that best separate the two populations shown in $\boldsymbol{F}$. 


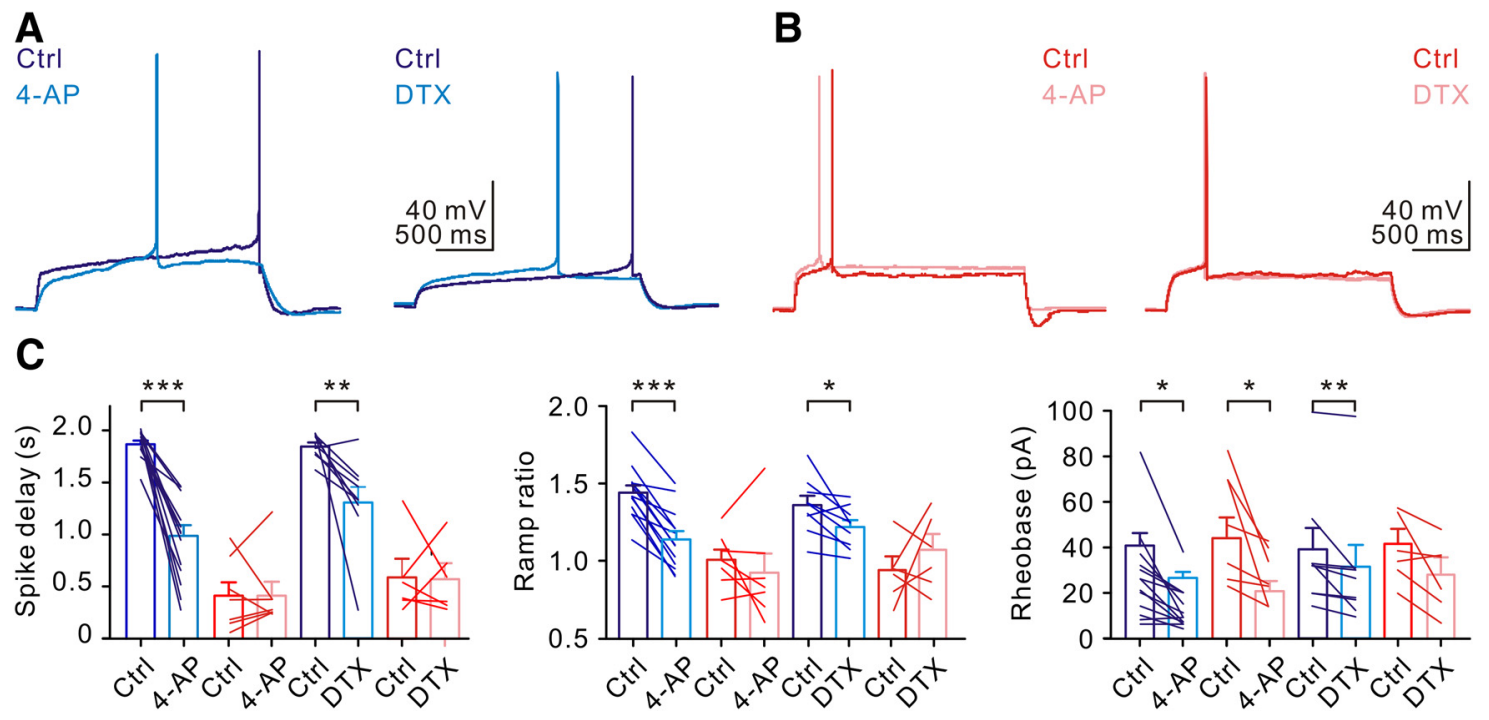

Figure 2. CeL neurons with different excitability showed differential sensitivity to $\mathrm{K}^{+}$channel blockers. $A$, Firing patterns of representative $L S$ cells in control (Ctrl, blue) and in the presence of $30 \mu \mathrm{m}$ 4-AP (left, light blue) or $100 \mathrm{~nm}$ DTX (right, light blue). Note the significant decreases in spike delay. B, Firing patterns of representative ES cells in Ctrl (red) and in the presence of $30 \mu \mathrm{m}$ 4-AP (left, light red) or $100 \mathrm{~nm}$ DTX (right, light red). C, Summary of spike delay, ramp ratio, and rheobase before and after 4-AP or DTX application. Solid lines are connected data obtained from the same cell. ${ }^{*} p<0.05 ;{ }^{* *} p<0.01 ;{ }^{* *} p<0.001$.

equipped with a $63 \times / 0.9$ numerical aperture water-immersion objective (objective type HCX APO L). The morphology of the cells was reconstructed from a stack of 121-165 images per cell (voxel size, $120-378 \mathrm{~nm}$ in the $x-y$ plane; $1 \mu \mathrm{m}$ along the $z$-axis). Image stacks belonging to one cell were imported into the Neuromantic 1.6.3 software (Myatt et al., 2012) for 3D reconstruction. Analysis of morphological parameters was performed using Neurolucida Explorer (MicroBrightField).

Data analysis and statistics. Data were analyzed using Clampfit version 10.3 (Molecular Devices) and Prism version 5.0 or 6.0 (GraphPad). The rheobase is the minimal intensity of $2 \mathrm{~s}$ current pulse required for AP generation. Briefly, neurons were held at $-70 \mathrm{mV}$ and depolarizing current steps (step increment $1 \mathrm{pA}$ ) were injected to induce APs. The spike delay was measured from the start of square depolarizing current pulse injection to the peak of the first AP evoked by the rheobase. The ramp ratio is the averaged membrane potential $\left(V_{\mathrm{m}}\right)$ between 0.2 to $0.25 \mathrm{~s}$ after the onset of subthreshold current pulse (intensity: $1 \mathrm{pA}$ less than the rheobase; $2 \mathrm{~s}$ ) injection versus the averaged $V_{\mathrm{m}}$ between 1.8 and $1.85 \mathrm{~s}$. The input resistance $\left(R_{\mathrm{N}}\right)$ was measured by the ratio of the steady-state (the last $100 \mathrm{~ms}$ ) voltage response versus the injected $1 \mathrm{~s}$ hyperpolarizing $(10 \mathrm{pA})$ current pulse. The membrane time constant $\left(\tau_{\mathrm{m}}\right)$ was calculated using a single-exponential fit to the late portion of the voltage change produced by hyperpolarizing $(50 \mathrm{pA})$ current pulse injection in the current-clamp mode at the RMP. The spike threshold was measured as the voltage at which the first derivative of voltage exceeded the threshold $(20 \mathrm{~V} / \mathrm{s})$. The synaptic latency was measured from the peak amplitude of the AP to the $10 \%$ rise time of the unitary IPSC (uIPSC) (Liu et al., 2014); the decay time constant of the uIPSC was fitted with a single exponential. The postsynaptic traces in the figures were averages of more than eight sweeps. The DSI response was quantified by normalizing the average uIPSC peak amplitude in the following $30 \mathrm{~s}$ right after the depolarization to that of the baseline uIPSC. Fisher's exact test was used for statistical comparison of the connectivity probabilities as described previously (Böhm et al., 2015). Data are presented as mean \pm SEM. Error bars in the figures equal SEM and are plotted only when they exceeded the respective symbol size. Because the normality of underlying distributions of variables in both groups is not known (Walker, 2002), we determined statistical significance by the Wilcoxon rank-sum (between groups of cells) or Wilcoxon signed-rank test (within groups of cells). Comparisons between multiple groups were tested by one-way ANOVA (with Tukey's post hoc test) or two-way ANOVA test (with Bonferroni post hoc test). The significance of correlation between the first uIPSC peak amplitude and multiple-pulse ratio/failure rate was determined by computing the Spearman rank correlation coefficient $\left(r_{\mathrm{s}}\right)$ and testing it against tabulated values (Spearman, 1904).

\section{Results \\ CeL neurons comprise two major functionally \\ distinct populations}

The amygdala is comprised of several distinct nuclei (Fig. 1A). In acutely prepared mouse amygdala slices, we identified the CeL by the surrounding axon bundles with IR-DIC optics (Fig. 1B) as described previously (Lopez de Armentia and Sah, 2004). Neurons in the CeL display heterogeneous intrinsic excitability (Martina et al., 1999; Lopez de Armentia and Sah, 2004; Chieng et al., 2006; Haubensak et al., 2010; Amano et al., 2012; Chiang et al., 2015). We first performed whole-cell patch-clamp recordings on cells and then made post hoc morphological reconstructions of the recorded cells. In agreement with previous results (Haubensak et al., 2010; Li et al., 2013), the majority ( 96\%, 217 of 225; Fig. 1C) of CeL neurons exhibited either the ES or the LS phenotype in response to depolarizing current steps, whereas only a small subset $(3.5 \%, 8$ of 225 ; Fig. 1C) displayed the lowthreshold-bursting (LTB) phenotype (Chieng et al., 2006). Because the onset of spikes varied in response to different current injections, we determined the spike delay (Fig. 1D) of the first AP upon a just suprathreshold current (i.e., rheobase) injection. Moreover, we determined the first AP properties, including the peak amplitude, voltage threshold, half-width, maximal rising rate, and maximal falling rate (see Materials and Methods). In addition to AP phenotypes, ES and LS cells differed in their subthreshold membrane responses (Fig. 1D). In striking contrast to ES cells, LS cells exhibited a slow ascending ramp in response to subthreshold current injection and displayed a greater ramp ratio (Table 1).

To further test whether ES and LS cells arise from two separate classes of CeL neurons or if they represent a single population of cells spanning a continuum of excitability, we analyzed several other physiological features (Table 1) from all non-LTB neurons. Overall, four features (spike delay, ramp ratio, RMP, and rheobase) showed non-Gaussian distributions (Fig. 1E). To divide 
these two distinct cell classes unbiasedly, we performed hierarchical cluster analysis from 90 randomly recorded CeL neurons based on these four features (Cossart et al., 2006; Graves et al., 2012; also see Materials and Methods). Strikingly, the cluster dendrogram yielded two distinct neuron populations, LS and ES cells (Fig. $1 F$ ). The spike delay of LS and ES neurons was $1776 \pm 21 \mathrm{~ms}$ (blue, $n=50)$ and $834 \pm 88 \mathrm{~ms}$ (red, $n=40)$, respectively $(p<$ 0.0001; Wilcoxon rank-sum test; Table 1). In addition, the LS population exhibited a more hyperpolarized RMP and a larger rheobase (Table 1). Similar to the dendrogram, the scatter-plot of spike delay versus ramp ratio revealed two distinctly nonoverlapping clusters (Fig. 1G). Classification of cells with the arbitrary cutoff value (spike delay of $1.5 \mathrm{~s}$ ) fell into two categories, which corresponded to the same two populations determined by the unbiased hierarchical cluster analysis. As a result, we classified neurons with a spike delay of $>1.5 \mathrm{~s}$ at rheobase as the LS cells and the remainders as the ES cells in the subsequent experiments of this study.

\section{LS and ES cells show differential sensitivity to the Kv1-channel blocker $\boldsymbol{\alpha}$-dendrotoxin}

A rich repertoire of ion channels shape the firing pattern of mammalian central neurons (Martina et al., 1998; Lien et al., 2003; Bean, 2007). Delayed or late-firing cells display a remarkably long delay to the initiation of the first AP. Moreover, application of long depolarizing steps to near the firing threshold gives rise to a long depolarizing ramp, suggesting the expression of slowly inactivating D-type $\mathrm{K}^{+}$current $\left(I_{\mathrm{D}}\right)$ (Storm, 1988; Martina et al., 1998; Goldberg et al., 2008; Kirchheim et al., 2013). The $I_{\mathrm{D}}$ is largely mediated by low-threshold voltage-gated $\mathrm{K}^{+}$type $1(\mathrm{Kv} 1)$ channel family, which is sensitive to low concentrations of 4-AP (e.g., $30 \mu \mathrm{M}$ ), a broad-spectrum $\mathrm{K}^{+}$channel blocker, and $\alpha$-DTX (100 nM), a specific Kv1 blocker (Martina et al., 1998; Dodson et al., 2002; Goldberg et al., 2008; Mathews et al., 2010; Kirchheim et al., 2013). We thus tested the effects of these pharmacological agents on the spike latency and depolarizing ramp. Indeed, bath application of $30 \mu \mathrm{M} 4$-AP significantly shortened the spike delay in LS cells (control, $1874 \pm 34 \mathrm{~ms}$ vs 4 -AP, $993 \pm 103 \mathrm{~ms}, n=13$; $p<0.001$; Wilcoxon signed-rank test; Fig. $2 A$, left traces, $C$, left), but not in ES cells (control, $411 \pm 129 \mathrm{~ms}$ vs 4 -AP, $412 \pm 134 \mathrm{~ms}$, $n=7 ; p=0.81$; Wilcoxon signed-rank test; Fig. $2 B$, left traces, $C$, left). Consistent with this, a low concentration of 4-AP $(30 \mu \mathrm{M})$ significantly increased the input resistance of LS cells (control, $351 \pm 16 \mathrm{M} \Omega$ vs 4 -AP, $395 \pm 20 \mathrm{M} \Omega, n=7 ; p<0.05$; Wilcoxon signed-rank test), but not that of ES cells (control, $380 \pm 19 \mathrm{M} \Omega$ vs 4 - $\mathrm{AP}, 373 \pm 17 \mathrm{M} \Omega, n=6 ; p=0.99$; Wilcoxon signed-rank test; data not shown). Similarly, $\alpha$-DTX (100 nM) significantly decreased the spike latency in LS cells (control, $1845 \pm 40 \mathrm{~ms}$ vs $\alpha$-DTX, $1306 \pm 149 \mathrm{~ms}, n=9$; $p<0.01$, Wilcoxon signed-rank test; Fig. $2 A$, right traces, $C$, left), but not in ES cells (control, $584 \pm 164 \mathrm{~ms}$ vs $\alpha$-DTX, $567 \pm 138 \mathrm{~ms}, n=6 ; p=0.84$, Wilcoxon signed-rank test; Fig. $2 B$, right traces). Furthermore, both 4 -AP $(30 \mu \mathrm{M})$ and $\alpha$-DTX $(100 \mathrm{nM})$ preferentially reduced the ramp ratio in LS cells (control, $1.45 \pm 0.05$ vs 4 -AP, $1.15 \pm 0.05$, $n=13 ; p<0.001$, Wilcoxon signed-rank test; Fig. $2 C$, middle; control, $1.36 \pm 0.06$ vs $\alpha$-DTX, $1.22 \pm 0.05, n=9$; $p<0.05$, Wilcoxon signed-rank test; Fig. $2 C$, middle). These effects are consistent with findings in other brain regions (Goldberg et al., 2008; Campanac et al., 2013) in which Kv1 channel blockade converted the LS cells to the ES-like phenotype.

Aside from the firing pattern, various types of $\mathrm{K}^{+}$channels regulate neuronal excitability for spike generation. Indeed, 4-AP reduced the rheobase current in both LS and ES cells (LS cell,
A
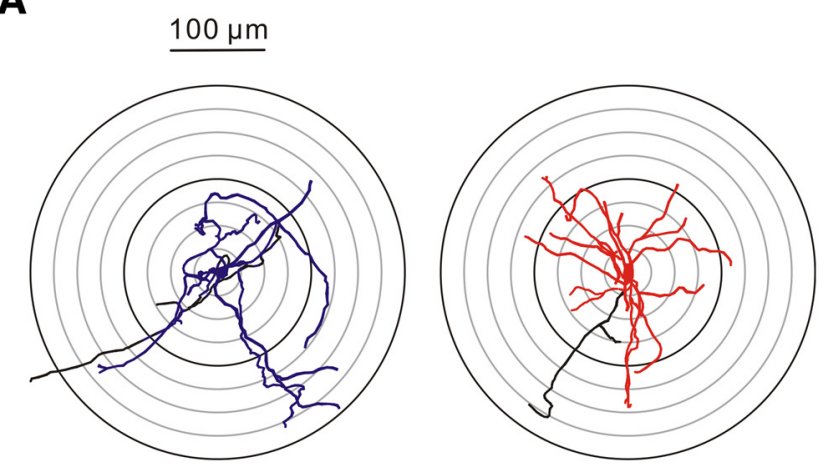

B

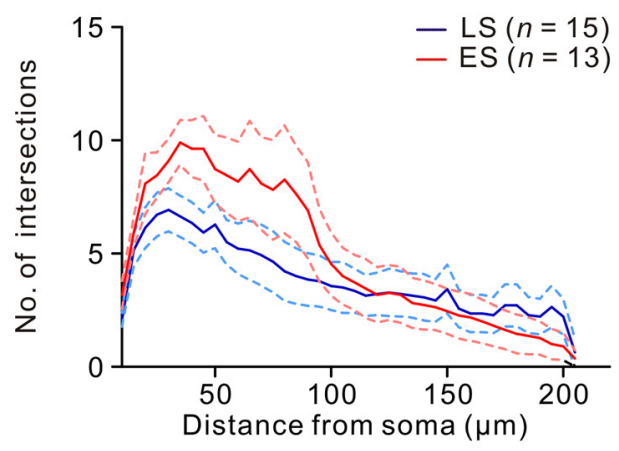

C

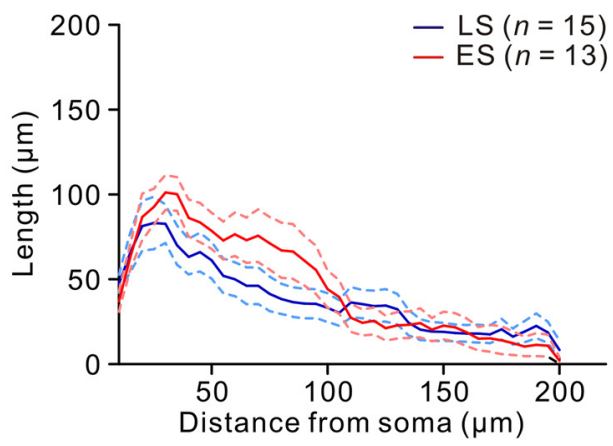

Figure 3. $\mathrm{LS}$ and $\mathrm{ES}$ cells had similar anatomical structures. $\boldsymbol{A}$, Examples of anatomical reconstructions of biocytin-filled LS (blue) and ES (red) cells. Soma and dendrites of the LS cell are drawn in blue. Soma and dendrites of the ES cell are drawn in red. Putative axons of the $L S$ and ES cells are drawn in black. $\boldsymbol{B}$, Sholl analysis of the number of dendritic intersections against the distance from soma. $\boldsymbol{C}$, Plot of dendritic length against the distance from soma. Solid and dashed lines indicate the average and SEM, respectively.

control, $40.4 \pm 5.5$ pA vs $4-\mathrm{AP}, 26.2 \pm 6.6 \mathrm{pA}, n=13 ; p<0.05$, Wilcoxon signed-rank test; Fig. $2 C$, right; ES cell, control, $43.7 \pm$ 9.1 pA vs 4-AP, $20.4 \pm 4.5 \mathrm{pA}, n=7 ; p<0.05$, Wilcoxon signedrank test; Fig. $2 C$, right). In contrast, $\alpha$-DTX, a specific Kv1 blocker, selectively reduced the rheobase in LS cells, but not in ES cells (LS cell, control, $38.7 \pm 9.2 \mathrm{pA}$ vs $\alpha$-DTX, $31.1 \pm 9.4 \mathrm{pA}, n=$ 9; $p<0.01$, Wilcoxon signed-rank test; Fig. $2 C$, right; ES cell, control, $40.7 \pm 6.4 \mathrm{pA}$ vs $\alpha$-DTX, $28.2 \pm 6.7 \mathrm{pA}, n=6 ; p=0.07$, Wilcoxon signed-rank test; Fig. $2 C$, right). These findings further corroborate the notion that Kv1 is expressed preferentially in LS cells.

LS and ES cells have similar anatomical features

Aside from distinguishing electrophysiological characteristics, we next searched for differences in morphological characteristics 
A
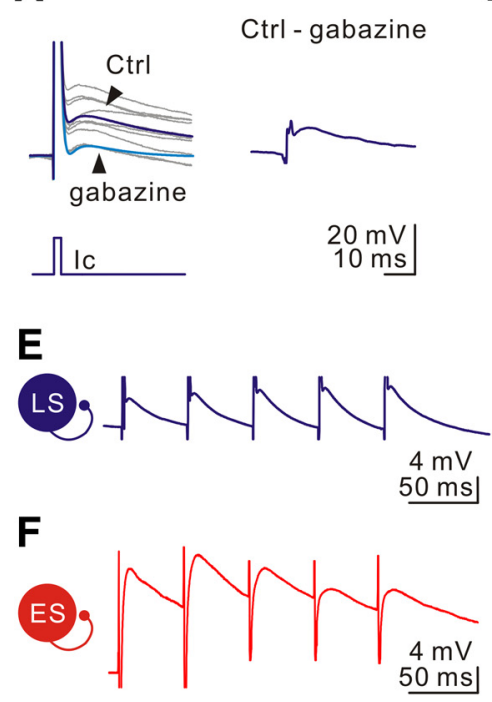

B

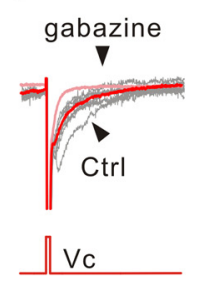

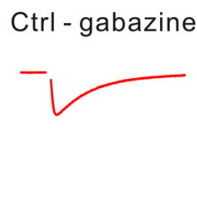

$100 \mathrm{pA}$ $10 \mathrm{~ms}$
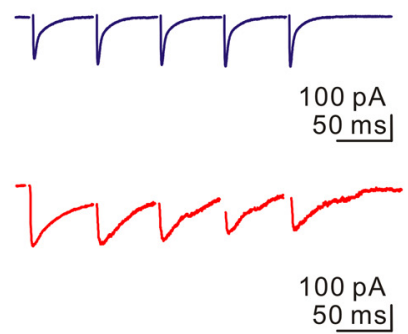

G
C D
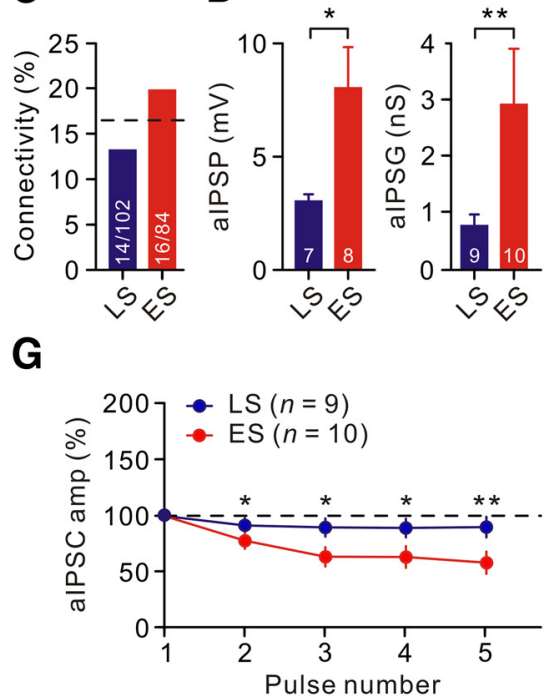

Figure 4. LS and ES cells displayed functionally distinct autaptic transmission. $A$, Left, APs (truncated for display purpose) evoked in an $\mathrm{LS}_{\text {cell }}$ were followed by depolarization ([Cl $\left.{ }^{-}\right]_{\mathrm{i}}=144 \mathrm{~mm}$ ), which was blocked by gabazine $(1 \mu \mathrm{m}$ ). Average traces (blue) were recorded before and after addition of gabazine; 10 overlaid individual sweeps (gray) were recorded in Ctrl. Right, average alPSP was obtained by digital subtraction of the average of 30 sweeps in the presence of gabazine from the average of 30 sweeps in Ctrl. $\boldsymbol{B}$, Left, Voltage steps to $+20 \mathrm{mV}$ from a holding potential of -70 $\mathrm{mV}$ in an ES cell elicited fast inward $\mathrm{Na}^{+}$current (truncated), followed by slower inward currents blocked by gabazine. Average traces (red) are shown in (trl and in the presence of gabazine, respectively; individual sweeps (gray) recorded in (trl. Right, Trace resulting after subtracting the gabazine average trace (from 30 sweeps) from the Ctrl average trace (from 30 sweeps). C, Bar graph of autaptic connectivity. Horizontal dashed line indicates the average connectivity in any type of CeL autapse. D, Summary of autaptic IPSP amplitude (left) and autaptic conductance (right) in LS and ES cells. ${ }^{*} p<0.05$; ${ }^{* *} p<0.01$. E, Train of 5 alPSPs (left; $I_{c^{\prime}}-70 \mathrm{mV}$, average of 30 sweeps) and alPSCs (right; $V c,-70 \mathrm{mV}$, average of 30 sweeps) evoked at $20 \mathrm{~Hz}$ were recorded from LScells; traces were isolated by gabazine. $\boldsymbol{F}$, Train of 5 alPSPs (left, average of 30 sweeps) and alPSCs (right, average of 30 sweeps) recorded from ES cells; the same protocol and recording configuration as in $\boldsymbol{E}$. G, Plot of alPSC amplitude (normalized to the first aIPSC in the same train) versus pulse number for each type of connections. The dashed line indicates a ratio of $1 .{ }^{*} p<0.05 ;{ }^{* *} p<0.01$.

between these functionally distinct neuronal populations by reconstructing biocytin-stained CeL neurons (Fig. 3A). Detailed morphometric analyses revealed that no consistent differences were found between LS and ES cells in the somatic size (LS cell, $16.7 \pm 1.1 \mu \mathrm{m}, n=15$ vs ES cell vs $17.4 \pm 1.2 \mu \mathrm{m}, n=13 ; p=$ 0.57 , Wilcoxon rank-sum test), total dendritic length (LS cell, $1514 \pm 165 \mu \mathrm{m}, n=15$ vs ES cell, $1778 \pm 273 \mu \mathrm{m}, n=13 ; p=$ 0.65 , Wilcoxon rank-sum test), and total branch points (LS cell, $10.0 \pm 0.9, n=15$ vs ES cell, $11.4 \pm 0.8, n=13 ; p=0.33$, Wilcoxon rank-sum test). Furthermore, Sholl analysis (Sholl, 1953) revealed that the number of dendritic intersections (LS cell, $n=15$; ES cell, $n=13 ; p=0.36$, 2-way ANOVA test; Fig. $3 B$ ) and the length of dendrite segments (LS cell, $n=15$; ES cell, $n=13$; $p=0.39,2$-way ANOVA test; Fig. $3 C$ ) were similar between these two neuronal populations. Therefore, both neuronal types have a similar anatomical structure.

\section{LS and ES cells display distinct autaptic neurotransmission}

GABAergic inhibitory neurons in the cortex can form selfinnervating synapses, namely autapses, as described previously (Tamás et al., 1997; Bacci et al., 2003; Connelly and Lees, 2010). In whole-cell current-clamp $\left(I_{\mathrm{c}}\right.$ at $-70 \mathrm{mV} ;\left[\mathrm{Cl}^{-}\right]_{\mathrm{i}}=144 \mathrm{~mm}$; corresponding to $E_{\mathrm{GABA}}=1.7 \mathrm{mV}$ ) recordings, we observed that APs in some CeL neurons were immediately followed by small slow membrane depolarization "bumps" (Fig. 4A). Such membrane bumps were blocked by gabazine $(1 \mu \mathrm{M})$, suggesting $\mathrm{GABA}_{\mathrm{A}}$ receptor-mediated depolarizing autaptic IPSP present in CeL neurons. Similarly, fast inward $\mathrm{Na}^{+}$currents were also followed by slower gabazine-sensitive inward currents (decay $\tau$, $36.6 \pm 1.3 \mathrm{~ms}, n=6$ ) when cells were briefly depolarized from -70 to $+20 \mathrm{mV}$ in voltage-clamp ( $\mathrm{Vc}$ ) (Fig. $4 B$ ). The autaptic connection rates of LS cells and ES cells were 13\% (13/98) and $19 \%$ ( 16 of 84$)$, respectively ( $p=0.43$, Fisher's exact test; Fig.
4C). On average, the autaptic IPSP (aIPSP) in ES cells was $8.0 \pm$ $2.5 \mathrm{mV}(n=8), \sim 4$-fold greater than that in LS cells $(2.2 \pm 0.4$ $\mathrm{mV} ; n=6 ; p<0.05$, Wilcoxon rank-sum test; Fig. $4 D$, left). Consistent with this, the autaptic conductance (aIPSG) was $2.9 \pm$ $1.1 \mathrm{nS}(n=10)$ in ES cells and $0.6 \pm 0.3 \mathrm{nS}(n=9)$ in LS cells $(p<$ 0.01 , Wilcoxon rank-sum test; Fig. $4 D$, right). We next investigated whether ES and LS cells differed in their autaptic properties. Gabazine-sensitive aIPSPs or currents (aIPSCs) were evoked by trains of $5 \mathrm{APs}$ at $20 \mathrm{~Hz}$ in the $I_{\mathrm{c}}$ configuration (Fig. $4 E, F$, left) or 5 brief depolarization steps at $20 \mathrm{~Hz}$ in the Vc configuration (Fig. $4 E, F$, right). As illustrated, aIPSPs or aIPSCs recorded in LS cells were slightly depressing (the ratio of fifth/first response, $91 \pm$ $11 \%, n=16$; Fig. $4 E$ ). In contrast, autaptic transmission in ES cells was strongly depressing (the ratio of fifth/first response, $58 \pm 11 \%, n=18$; Fig. $4 F)$, significantly different from that in LS cells $(p<0.01$, Wilcoxon rank-sum test; Fig. $4 G)$. Overall, our data revealed that autaptic transmission in ES cells is robust but transient during $20 \mathrm{~Hz}$ trains of activation compared with that in LS cells.

\section{Autaptic transmission enhances spike-timing precision in ES cells}

GABAergic transmission results in hyperpolarization after single APs and thus sets the timing of subsequent spikes in a train (Bacci and Huguenard, 2006; Woodruff and Sah, 2007). To investigate the physiological impact of autapses, neurons were held at -50 $\mathrm{mV}$ and depolarized by repeated identical suprathreshold current injections to spike at $6-10 \mathrm{~Hz}$. The timing of each spike in both neurons varied from trial to trials (Fig. $5 A, B$ ). We next compared the effect of autaptic transmission on spike-timing precision in LS cells versus ES cells. The analysis was restricted to the aIPSC that was $>3$ times the SD of the preceding baseline when recorded at $-50 \mathrm{mV}\left(\left[\mathrm{Cl}^{-}\right]_{\mathrm{i}}=7.2 \mathrm{mM}\right)$ in the Vc configuration. As 
A
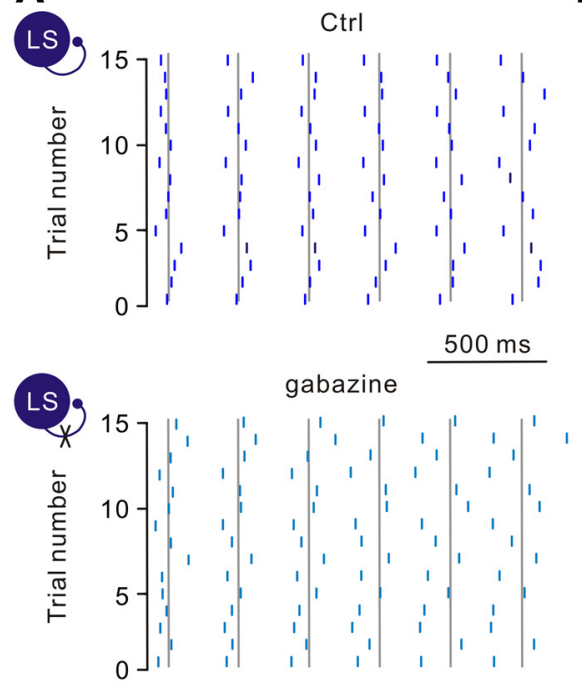

C

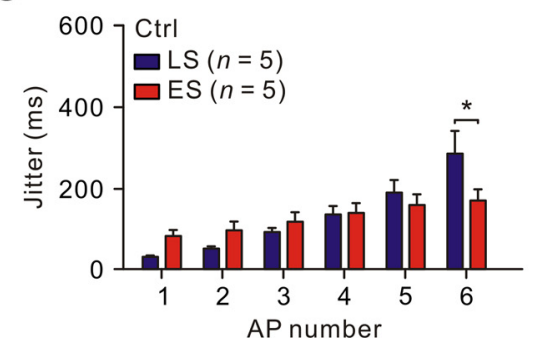

E

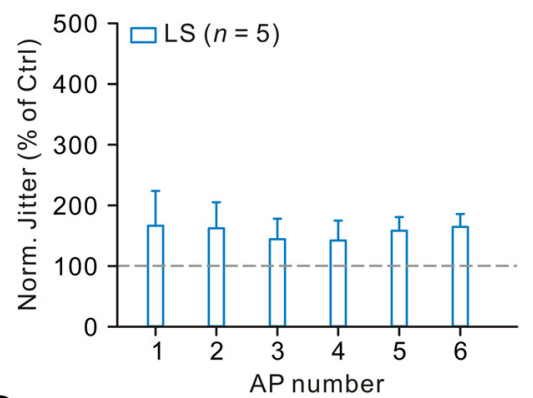

G

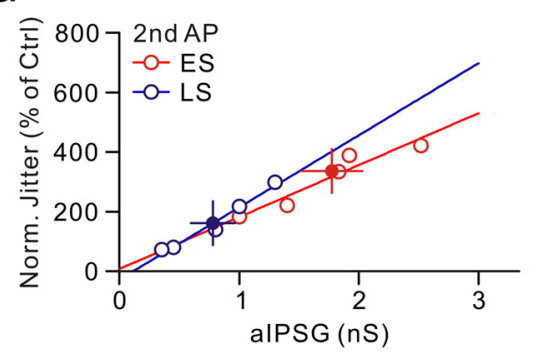

B
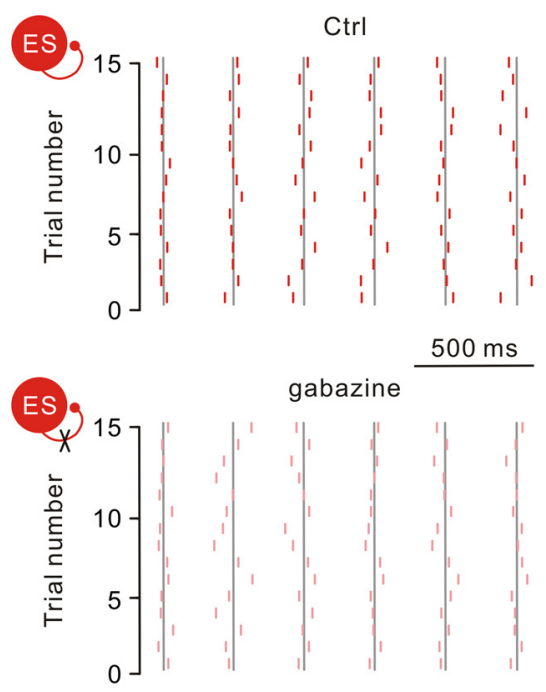

D

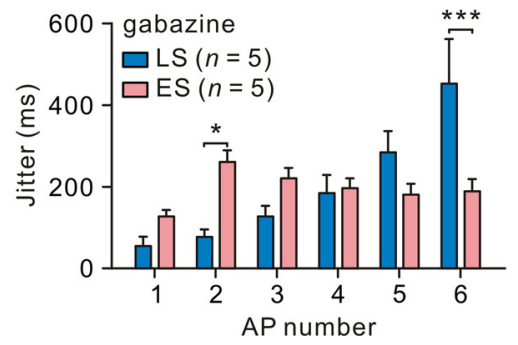

$\mathbf{F}$

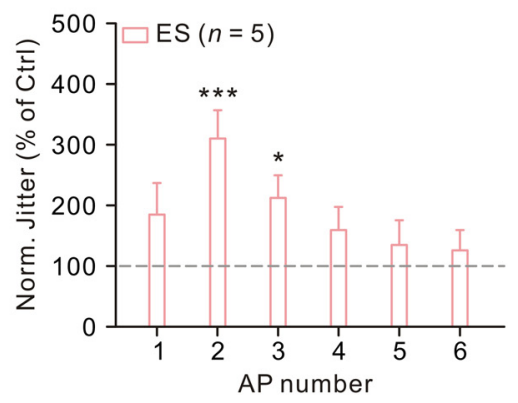

H

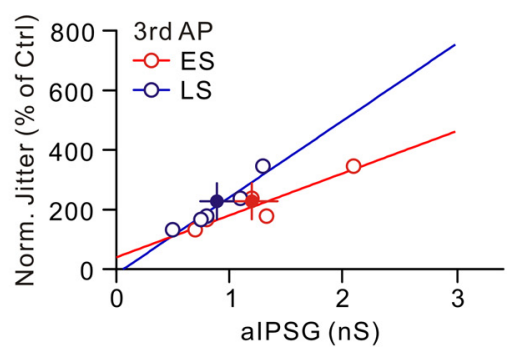

(Fig. 5C). Notably, the spike jitter was significantly greater in LS cells than ES cell at the sixth spike in the train $(p<0.001$, post hoc Bonferroni test after 2-way ANOVA; Fig. 5C). After blockade of GABAergic autaptic transmission, the jitter of each spike during a train of both autapse-containing CeL neuron types was modestly increased (1 $\mu \mathrm{M}$ gabazine; Fig. 5D). Notably, the jitter of the second spike in ES cells became significantly greater than that in LS cells $(p<0.05$, post hoc Bonferroni test after 2-way ANOVA; Fig. 5D). Although there was a small increase of jitters in LS cells by gabazine application, this effect was not significant $(n=5, p=0.11,2$-way ANOVA test; Fig. 5E). In striking contrast, the jitters of the second and third spikes in ES cells were significantly increased by gabazine ( $n=5$, the normalized second spike jitter, $310 \pm 50 \%$ of control, $p<$ 0.001 ; the normalized third spike jitter, $210 \pm 40 \%$ of control, $p<0.05$; post hoc Bonferroni test after 2-way ANOVA test; Fig. 5F). These results indicated that autaptic transmission in ES cells enhances the spike-timing precision during trains of activation.

Finally, we examined the impact of aIPSG on the second and third spike jitters. We first analyzed the correlation of aIPSG versus spike jitter in gabazine (normalized to jitter of control). We found that the magnitude of aIPSG positively correlated with the jitter change after blockade of autaptic transmission by gabazine (Fig. $5 G, H)$. Furthermore, the second spikeevoked aIPSGs in ES cells were 2-fold greater than those in LS cells (ES cell: $1.7 \pm$ $0.3 \mathrm{nS}$ for vs LS cell: $0.8 \pm 0.2 \mathrm{nS} ; p<0.05$; Wilcoxon rank-sum test; Fig. $5 G$ ). It is notable that, although gabazine caused a small increase in the third spike jitter in ES cells, the third spike-evoked aIPSGs in ES and LS cells were quite similar (ES cell: $1.2 \pm 0.3 \mathrm{nS}$ for vs LS cell: $0.9 \pm 0.1 \mathrm{nS} ; p=$ 0.34; Wilcoxon rank-sum test; Fig. $5 H$ ). In sum, these results indicate that the efficacy of autaptic conductance may account for the cell-type-specific enhancement of spike-timing precision.

Figure 5. Selective enhancement of spike-timing precision by autaptic transmission in ES cells. $\boldsymbol{A}, \boldsymbol{B}$, Top, Raster plots of firing of $L S(\boldsymbol{A}$, blue) and $E S(\boldsymbol{B}$, red) neurons in response to 15 identical suprathreshold current injections $(2 \mathrm{~s}, 10-20 \mathrm{pA})$. The gray line marks the average timing of each spike. Bottom, Raster plots of the same neurons after gabazine application. $C, D$, Plot of spike jitter against AP number of both $\mathrm{LS}$ and $\mathrm{ES}$ autapse-containing cells before and after gabazine application. $E, F$, Plot of normalized jitter against spike number in $L S(n=5)$ and $E S(n=5)$ cells. Note that jitters in ES cells at the second and third spikes in the train were significantly increased. $\boldsymbol{G}, \boldsymbol{H}$, Plot of normalized jitters of the second $(\boldsymbol{G})$ and third $(\boldsymbol{H})$ spike against alPSG. Curves represent linear fits to open circles. Filled circles are averages. ${ }^{*} p<0.05 ;{ }^{* * *} p<0.001$.

described previously (Bacci and Huguenard, 2006), we quantified spike-timing precision as spike jitter, defined as the SD of the ordinal spike times across multiple identical stimulation trials. Both LS and ES cells had progressive increases in the spike jitters lated GABA release of a specific cell type, we performed simultaneous paired recordings from identified cell types and then applied a DSI protocol known to trigger retrograde release of eCB and to suppress phasic GABA release (Ramikie et al., 2014). In-

\section{Presynaptic cell type dictates DSI}

Endocannabinoid (eCB) signaling modulates GABA transmission in the CeA (Roberto et al., 2010). However, only a few GABAergic terminals in the $\mathrm{CeL}$ are $\mathrm{CB}_{1^{-}}$ receptor positive (Ramikie et al., 2014). To address whether eCB specifically modu- 
A
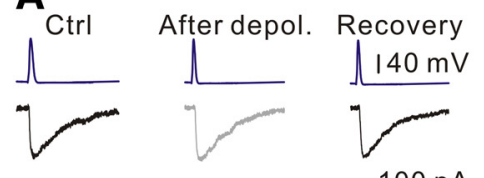

$100 \mathrm{pA}$

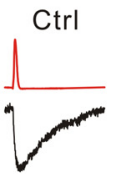

After depol. Recovery
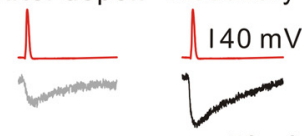

$50 \mathrm{pA}$
$10 \mathrm{~ms}$

D
B
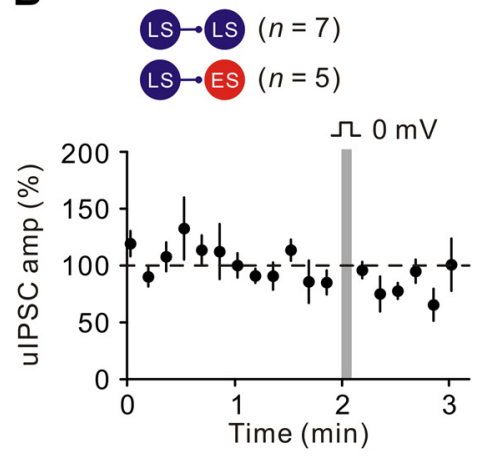

E

C
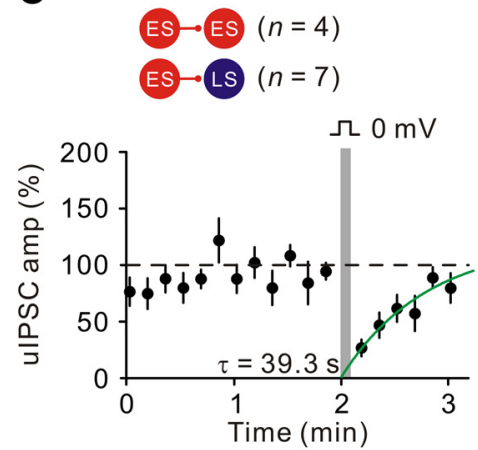

F

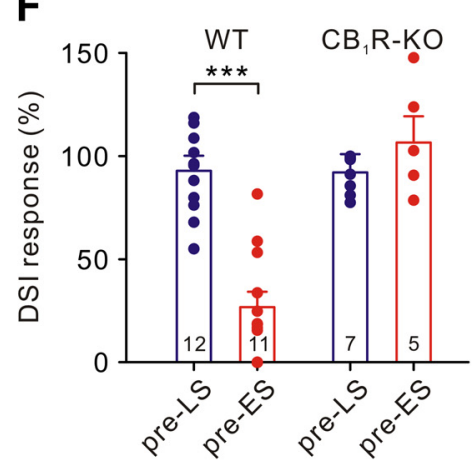

Figure 6. Presynaptic ES-cell-specific depolarization-induced suppression of inhibition. $\boldsymbol{A}$, Top, Representative uIPSC traces in Ctrl, after depolarization, and recovery from DSI of the CeL synapses in which the presynaptic phenotype is LS. To induce the DSI, postsynaptic cells were depolarized to $0 \mathrm{mV}$ from $-70 \mathrm{mV}$ under Vc for $10 \mathrm{~s}$. Bottom, Representative uIPSC traces of the CeL synapses in which the presynaptic phenotype is ES. $B$, Summary of the uIPSC versus time from $L S \rightarrow L S(n=7)$ or $L S \rightarrow E S(n=5)$ pairs, with the voltage command shown on the top side. Gray bar indicates the time of DSI induction. $\boldsymbol{C}$, Summary of the uIPSC versus time from ES $\rightarrow E S(n=4)$ or $E S \rightarrow L S(n=7)$ pairs. The recovery time course is fitted with a single exponential function. $\boldsymbol{D}$, Example of reciprocally connected ES and LS neurons revealing that DSI is specific to presynaptic ES cells. $E$, Lack of DSI in CB, R KO mice. $F$, Summary of DSI responses (average uIPSCs from 0 to 10 s right after the DSI protocol was normalized to baseline uIPSCS) of pairs with presynaptic LS cell $(n=12)$ and presynaptic ES cell $(n=11)$ in wild-type mice (WT) or in CB $\mathrm{R}_{1}-\mathrm{KO}_{0}$ mice (presynaptic $\mathrm{LS}$ cell, $n=$ 7; presynaptic ES cell, $n=5$ ). ${ }^{* * *} p<0.001$.

terestingly, we found that DSI was exclusively present at the synapses, in which presynaptic cells was the ES phenotype (Fig. 6A-C). After the DSI induction, the uIPSC amplitude was immediately decreased by $73 \pm 7 \%(n=12)$ and gradually recovered to the baseline (Fig. $6 C$ ). The recovery time course was fitted with a mono-exponential function with a time constant of $39.3 \mathrm{~s}$. As illustrated in a reciprocally connected ES and LS cell pair (Fig. 6D), we found a clear distinction: the DSI indeed occurred at the ES $\rightarrow$ LS synapse, but not at the LS $\rightarrow$ ES synapse. In sum, the DSI is independent of postsynaptic cell types, suggesting that eCB mobilization occurs in both ES and LS cells during the DSI induction (4 ES cells and 7 LS cells; Fig. $6 C)$. Consistent with this notion, DSI was not present in $\mathrm{CB}_{1^{-}}$ receptor $\mathrm{KO}$ mice (Fig. $6 E$ ). Retrograde $\mathrm{eCB}$ signaling that selectively mediates short-term forms of plasticity at ES neuron output synapses (Fig. $6 F$ ) represents a biochemical substrate for functional segregation between ES and LS neuron types.

\section{Both presynaptic and postsynaptic cell types determine synaptic properties}

We next investigated whether each CeL neuron class forms synapses with highly specific temporal dynamics onto target neurons. To address this, we examined both divergent and convergent synapses using simultaneous triple whole-cell patch-clamp recordings. For the divergent connections (Fig. 7A), we elicited a train of $5 \mathrm{APs}$ at $20 \mathrm{~Hz}$ in a presynaptic neuron and simultaneously recorded uIPSCs were from two different classes of postsynaptic neurons. We found that the ES $\rightarrow$ ES synapse was weakly depressing $\left(\mathrm{uIPSC}_{5} / \mathrm{uIPSC}_{1}=0.86\right.$; Fig. $7 \mathrm{~A}$, left), whereas the $\mathrm{ES} \rightarrow \mathrm{LS}$ synapse was strongly depressing $\left(\mathrm{uIPSC}_{5} / \mathrm{uIPSC}_{1}=0.14\right.$; Fig. 7A, right). These results indicate differential synaptic modifications via the same axon innervating two different targets (Markram et al., 1998; Buchanan et al., 2012; Sylwestrak and Ghosh, 2012; see review by Blackman et al., 2013). In an example of convergent synaptic connections (Fig. $7 B$ ), we recorded responses from a neuron innervated by two different classes of presynaptic neurons. Consistent with the above findings, the $\mathrm{ES} \rightarrow \mathrm{ES}$ synapse was weakly depressing $\left(\mathrm{uIPSC}_{5} / \mathrm{uIPSC}_{1}=0.81\right.$; Fig. $7 B$, left). Conversely, the $\mathrm{LS} \rightarrow \mathrm{ES}$ synapse was strongly depressing ( uIPSC $_{5} / \mathrm{uIPSC}_{1}=0.31$; Fig. $7 B$, right). Therefore, unlike those found in other brain regions where properties of inhibitory synapses were determined by either presynaptic or postsynaptic cell types (Geracitano et al., 2007; Ma et al., 2012; see review by Blackman et al., 2013; Liu et al., 2014), the identities of both presynaptic and postsynaptic cells determined the properties of CeL inhibitory synapses.

In addition to unidirectional connections, we also detected bidirectional connections between CeL neurons. Consistent with the results obtained from pairs and triplets, synapses between two different classes were strongly depressing. As illustrated in Figure $7 C$, synapses between mutually connected ES and LS cells showed marked depression $\left(\mathrm{ES} \rightarrow \mathrm{LS}, \mathrm{uIPSC}_{5} / \mathrm{uIPSC}_{1}=0.63\right.$; LS $\rightarrow \mathrm{ES}$, $\mathrm{uIPSC}_{5} / \mathrm{uIPSC}_{1}=0.56$; Fig. $7 C$ ). Conversely, synapses between cells of the same class showed weak plasticity $(\mathrm{ES} \# 1 \rightarrow \mathrm{ES} \# 2$, $\mathrm{uIPSC}_{5} / \mathrm{uIPSC}_{1}=1.03 ; \mathrm{ES} \# 2 \rightarrow \mathrm{ES} \# 1, \mathrm{uIPSC}_{5} / \mathrm{uIPSC}_{1}=1.28 ; \mathrm{LS}$ $\# 1 \rightarrow \mathrm{LS} \# 2, \mathrm{uIPSC}_{5} / \mathrm{uIPSC}_{1}=0.79 ; \mathrm{LS} \# 2 \rightarrow \mathrm{LS} \# 1, \mathrm{uIPSC}_{5} /$ uIPSC $_{1}=0.71$; Fig. $\left.7 D, E\right)$. 
A

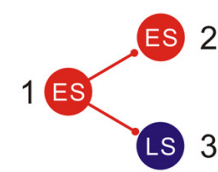

$1 \rightarrow 2$

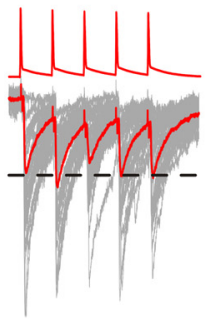

C

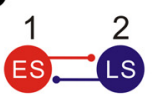

$1 \rightarrow 2$

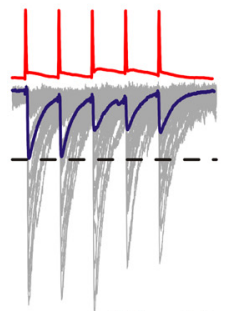

$20 \mathrm{mV}$

$50 \mathrm{pA}$

$50 \mathrm{~ms}$

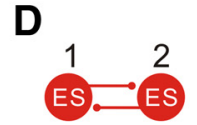

$1 \rightarrow 2$

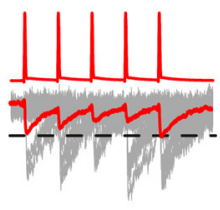

$20 \mathrm{mV}$

$50 \mathrm{~ms}$
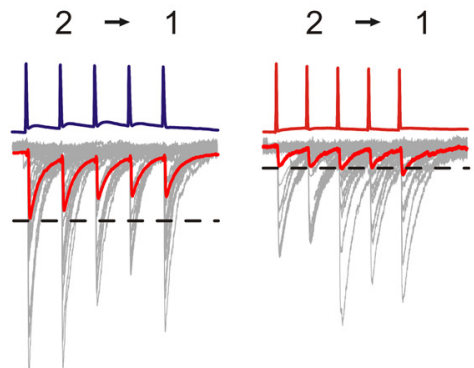

B

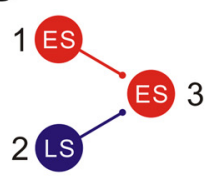

$1 \rightarrow 3$

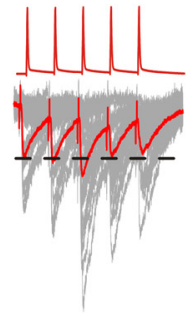

$20 \mathrm{mV}$
$80 \mathrm{pA}$ $50 \mathrm{~ms}$
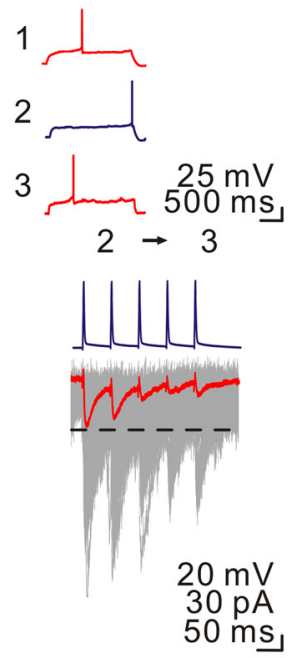

E

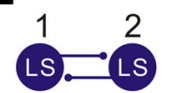

$1 \rightarrow 2$

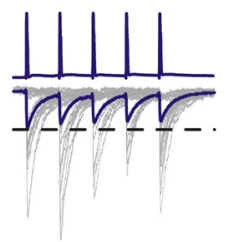

$20 \mathrm{mV}$ $50 \mathrm{pA}$ $50 \mathrm{~ms}$

G

$\mathbf{F}$
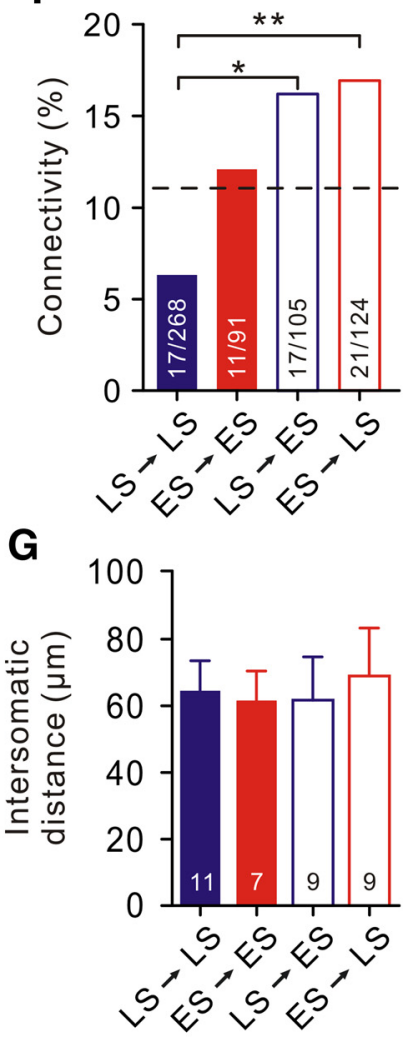

Figure 7. Specificity of GABAergic neurotransmission between CeL neurons. $A$, Example of divergent connections from an ES cell onto two distinct target cells. The presynaptic ES cell was stimulated by brief pulses of intracellular current injection. Simultaneous whole-cell V c recordings of ulPSCs were made from an ES and an LS cell. Representative firing patterns are shown. Average uIPSCs are shown in bold traces superimposed on 30 example unitary responses (gray traces). $\boldsymbol{B}$, Example of convergent connections from an ES cell and an $\mathrm{LS}$ cell onto a common target ES cell and their representative firing patterns. Average traces recorded from the $E S \rightarrow E S$ (left) and $L S \rightarrow E S$ (right) synapses are shown in bold traces superimposed on 30 example unitary responses (gray traces). C, Example of reciprocally connected ES and LS cells. Note that the ES $\rightarrow L S$ and $L S \rightarrow E S$ synapses showed similar shortterm depression. $\boldsymbol{D}$, Example of reciprocal connection between two ES cells. Note that ES\#1 $\rightarrow$ ES \#2 and ES\#2 $\rightarrow$ ES\#1 connections showed similar synaptic dynamics and little depression. $\boldsymbol{E}$, Example of two reciprocally connected LS cells. $\boldsymbol{F}$, Summary of the connectivity of CeL cells. The number of connections per number of attempts in each type of pair is indicated. The dashed line indicates the mean connectivity of any CeL neurons. G, Bar graph comparing intersomatic distance between chemically coupled neurons. Number of pairs is indicated. ${ }^{*} p<0.05 ;{ }^{* *} p<0.01$.

In total, 66 of 588 pairs (11.2\%) showed chemical synaptic responses. In contrast, we did not detect any electrically coupled response in all pairs ( 0 of 588; see Materials and Methods). The connection rates of the LS $\rightarrow$ ES and ES $\rightarrow$ LS synapses were signif-

icantly higher than that of the LS $\rightarrow$ LS synapse $(\mathrm{LS} \rightarrow$ ES group, $16.1 \%$ vs LS $\rightarrow$ LS group, $6.3 \%$; $p<0.05$, Fisher's exact test; $\mathrm{ES} \rightarrow$ LS group, $16.9 \%$ vs LS $\rightarrow$ LS group, $6.3 \% ; p<0.01$, Fisher's exact test; Fig. $7 F$ ), but were similar to that of the $\mathrm{ES} \rightarrow \mathrm{ES}$ synapse (LS $\rightarrow$ ES group, $16.1 \%$ vs ES $\rightarrow$ ES group, $12.1 \% ; p=0.55$, Fisher's exact test; $\mathrm{ES} \rightarrow$ LS group, $16.9 \%$ vs $\mathrm{ES} \rightarrow$ ES group, $12.1 \% ; p=0.45$, Fisher's exact test; Fig. $7 F)$. Overall, the average distances between the somata of these four types of connections were not significantly different ( $p=0.97,1$-way ANOVA test; Fig. $7 G$ ). Therefore, preferential synapse formation between distinct cell types may be critical for microcircuits formed among inhibitory neurons.

Analysis of all CeL neuron pairs revealed that STP by a train of presynaptic stimulation at $20 \mathrm{~Hz}$ showed little depression at the $\mathrm{ES} \rightarrow \mathrm{ES} \quad\left(\mathrm{uIPSC}_{5} / \mathrm{uIPSC}_{1}\right.$, $102 \pm 10 \%$ ) or LS $\rightarrow$ LS cell (uIPSC ${ }_{5} /$ uIPSC $_{1}, 87 \pm 5 \%$ ) connection (Fig. $8 A, B$; Table 2). In contrast, the ES $\rightarrow$ LS or LS $\rightarrow$ ES cell connection showed strong multiple-pulse depression (ES $\rightarrow$ LS group, $\mathrm{uIPSC}_{5} / \mathrm{uIPSC}_{1}, 29 \pm 3 \%$; LS $\rightarrow$ ES group, uIPSC $_{5} /$ uIPSC $_{1}, 30 \pm 4 \%$; Fig. $8 C$, Table 2). To determine whether STP of CeL synapses was preserved at the physiological temperature, we also tested STP at $34^{\circ} \mathrm{C}$ and found similar results; therefore, these results were pooled in Figure 8.

Similar to STP, the synaptic efficacy (estimated by the UIPSC $_{1}$ amplitude) was also specific to presynaptic and postsynaptic cell classes (Table 2). On average, the $\mathrm{uIPSC}_{1}$ amplitudes at the ES $\rightarrow \mathrm{ES}(34.2 \pm$ $3.9 \mathrm{pA}, n=10)$ and $\mathrm{LS} \rightarrow \mathrm{LS}(28.7 \pm 5.2$ $\mathrm{pA}, n=15)$ synapses were significantly smaller than those at the LS $\rightarrow$ ES (145.4 \pm $47.1 \mathrm{pA}, n=13)$ and $\mathrm{ES} \rightarrow \mathrm{LS}(177.2 \pm$ $40.3 \mathrm{pA}, n=20)$ synapses $(p<0.001$, 1-way ANOVA test; Table 2). Consistently, the failure rate of evoking the $\mathrm{uIPSC}_{1}$ at the ES $\rightarrow \mathrm{ES}(44.0 \pm 5.0 \%, n=$ $10)$ or LS $\rightarrow$ LS $(40.0 \pm 8.0 \%, n=15)$ synapse was significantly greater than that at the $\mathrm{ES} \rightarrow \mathrm{LS}(14.0 \pm 3.0 \%, n=20)$ or LS $\rightarrow$ ES $(16.0 \pm 3.0 \%, n=13)$ synapse $(p<0.01,1$-way ANOVA test; Table 2). Moreover, the IIPSC $_{1}$ amplitude inversely correlated with the multiple-pulse ratio ( $\mathrm{uIPSC}_{5} / \mathrm{uIPSC}_{1}$ ) by performing $r_{\mathrm{s}}$ analysis $\left(r_{\mathrm{s}}=-0.50, p<0.0001\right.$; Fig. $\left.8 E\right)$. This observation is consistent with the notion (Debanne et al., 1996) that strong synapses (e.g., the ES $\rightarrow$ LS or LS $\rightarrow$ ES synapse) with a high initial release probability exhibit strong depression during multiple stimulation at a high frequency. Similarly, the peak amplitude of uIPSC $_{1}$ was inversely proportional to the failure rate $\left(r_{\mathrm{s}}=-0.70, p<0.0001\right.$; Fig. $\left.8 F\right)$. 
Cell-type-specific STP is independent of the cell marker somatostatin

CeL neurons express neurochemical markers such as the neuropeptide somatostatin $(\mathrm{SOM})$ or protein kinase $\mathrm{C}-\delta$ (PKC- $\delta$ ) (Cassell et al., 1986; Haubensak et al., 2010; Li et al., 2013; Penzo et al., 2014). $\mathrm{SOM}^{+}$and $\mathrm{PKC}-\delta^{+}$neurons are largely nonoverlapping (Li et al., 2013). Here, we also identified $\mathrm{SOM}^{+}$neurons that readily expressed the red fluorescent protein tdTomato in Som-IRES-cre;Ail4 mice (Fig. 9A). We observed that both $\mathrm{SOM}^{+}$ and $\mathrm{SOM}^{-}$neurons exhibited a high degree of variation in the spike delay (Fig. $9 B)$. Furthermore, cumulative distribution of spike delays from $\mathrm{SOM}^{+}$and $\mathrm{SOM}^{-}$neurons showed a similar pattern ( $p=0.11$; Kolmogorov-Smirnov test). In agreement with a recent report ( $\mathrm{Li}$ et al., 2013), we found that $54 \%$ ( 14 of 26 cells, cells located left to the vertical dashed line) of $\mathrm{SOM}^{+}$cells were the ES phenotype (Fig. 9B), similar to that $(55 \% ; 12$ of 22 cells) of $\mathrm{SOM}^{-}$cells. Altogether, the neurochemical marker SOM did not correlate with intrinsic excitability.

We next sought to investigate synaptic connectivity and transmission between neurons based on the expression of SOM in the presynaptic and postsynaptic neurons. There were four types of connections and they displayed similar multiple-pulse depression $\left(\mathrm{SOM}^{+} \rightarrow \mathrm{SOM}^{+}\right.$, $52 \pm 15 \% ; \mathrm{SOM}^{-} \rightarrow \mathrm{SOM}^{-}, 59 \pm 16 \%$; $\mathrm{SOM}^{+} \rightarrow \mathrm{SOM}^{-}, 57 \pm 16 \% ; \mathrm{SOM}^{-} \rightarrow$ $\mathrm{SOM}^{+}, 56 \pm 13 \% ; p=0.99,1$-way ANOVA test; Fig. 9C). Notably, if we presented the same dataset according to ES and LS cell phenotypes, the STP of these synapses was highly predictable from the presynaptic-postsynaptic interaction principle $(\mathrm{LS} \rightarrow \mathrm{LS}, 80 \pm 5 \%$; $\mathrm{ES} \rightarrow \mathrm{ES}$, $124 \pm 11 \% ; \mathrm{LS} \rightarrow \mathrm{ES}, 28 \pm 3 \% ; \mathrm{ES} \rightarrow \mathrm{LS}$, $33 \pm 6 \% ; p<0.0001,1$-way ANOVA test; Fig. 9D). These results indicate that the synaptic strength and STP of CeL synapses are independent of SOM expression.

\section{Cell-type-specific STP controls output spike patterns}

Finally, we probed the functional conse-

quences of the cell-type-specific STP. We first obtained paired recordings from synaptically coupled pairs and characterized their synaptic dynamics. Consistent with our observation, all recordings here showed that synapses between electrically heterogeneous neurons were strong and markedly depressing, whereas synapses between electrically homogeneous neurons were weak and slightly facilitating or depressing. Therefore, we classified synapses into strong, depressing synapses (Fig. 10A) versus weak, nondepressing synapses (Fig. 10B). We next elicited APs in postsynaptic neurons by trains of brief current injections at $20 \mathrm{~Hz}$. The magnitude of brief current injection was adjusted such
B
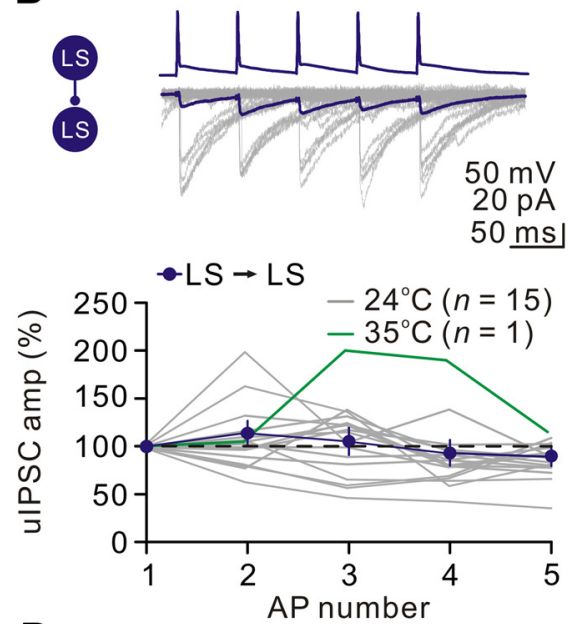

D
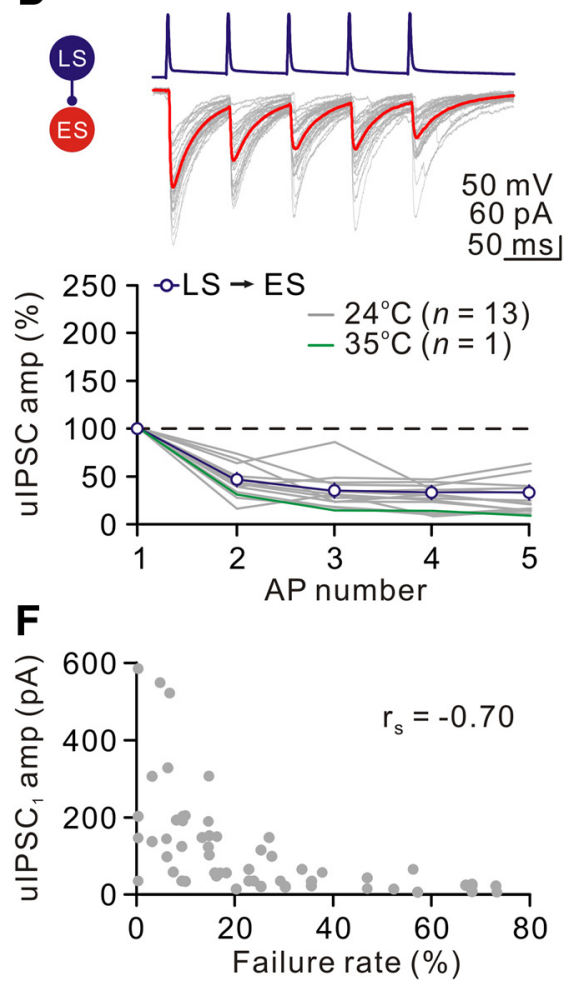

Figure 8. Presynaptic and postsynaptic cell-type-specific STP. $\boldsymbol{A}-\boldsymbol{D}$, Representative records from unidirectionally connected $\mathrm{ES} \rightarrow \mathrm{ES}, \mathrm{LS} \rightarrow \mathrm{LS}, \mathrm{ES} \rightarrow \mathrm{LS}$, and $\mathrm{LS} \rightarrow \mathrm{ES}$ pairs. The presynaptic neurons were fired at $20 \mathrm{~Hz}$ (top trace); the bottom example traces show the averaged postsynaptic responses (from 50 single traces; failures included) recorded at a holding potential of $-70 \mathrm{mV}$ $\left(\left[\mathrm{Cl}^{-}\right]_{\mathrm{i}}=144 \mathrm{~mm}\right)$. Traces are color coded by subtype (ES, red; $\mathrm{LS}$, blue). Graph, Average amplitudes normalized to the amplitude

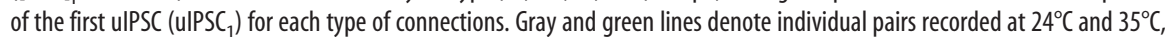
respectively. The horizontal dotted lines indicate a ratio of 1 . $\boldsymbol{E}$, Plot of average uIPSC amplitude against the amplitude ratio (uIPSC $_{5} /$ uIPSC $_{1}$ ) for each type of connection. $\boldsymbol{F}$, Plot of average uIPSC $C_{1}$ amplitude against the failure rate of the uIPSC $C_{1}$.

that firing probabilities were kept at $\sim 0.5$. To determine whether a single presynaptic neuron could control neuronal output (Woodruff and Sah, 2007), we induced a presynaptic neuron firing $10 \mathrm{~ms}$ before the postsynaptic current injection (Fig. $10 C, D)$. As exemplified here, a strong depressing synapse profoundly suppressed the initial spike generation (spike probability, $0.58 \pm 0.03$ without presynaptic spikes vs $0.34 \pm 0.02$ with presynaptic spikes, $n=6$; $p<0.05$, Wilcoxon signed-rank test; Fig. 10E). In contrast, there was no changes in neurons with a weak nondepressing synapse (spike probability, $0.55 \pm 0.03$ without presynaptic spikes vs $0.48 \pm 0.04$ with presynaptic 
Table 2. Properties of ulPSCs generated at GABAergic synapses

\begin{tabular}{|c|c|c|c|c|c|}
\hline & $S(10)$ & $L S \rightarrow L S(15)$ & $S(20)$ & $\rightarrow E S(13)$ & \\
\hline ) & 1.92 & $-0.2 J$ & & & \\
\hline & 1.7 & & & & $4^{a}$ \\
\hline ) & 33.1 & -1.0 & 9 & $\angle U$ & 0.06 \\
\hline$e$ & 34.2 & 28. & & & \\
\hline ) & 44 & \pm 8 & 14 & 16 & 0.00 \\
\hline & 1.21 & 1.0 & & & $<0.00$ \\
\hline & 1.02 & 0.8 & & & $<0.0001^{e}$ \\
\hline+ & 0.88 & 0.73 & & & 0.00 \\
\hline \multicolumn{6}{|c|}{ 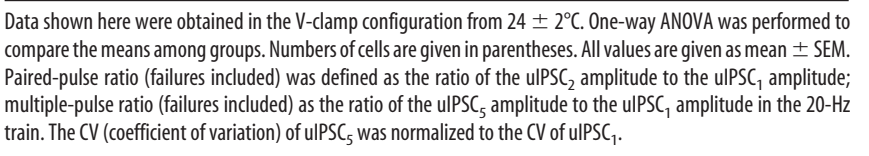 } \\
\hline \multicolumn{6}{|c|}{$\begin{array}{l}{ }^{a} p<0.05 ; \text { group } 3<1 \text { by Tukey's post hoc test, } p=0.0001 ; \text { Group } 4<1 \text { by Tukey's post hoc test, } p<0.0001 \text {; } \\
\text { Group } 3<2 \text { by Tukey's post hoc test, } p<0.01 ; \text { Group } 4<2, p=0.0001 \text { by Tukey's post hoc test; Group } 1 \text { versus } \\
2, p=0.70 ; \text { Group } 3 \text { versus } 4, p=0.86 \text {. }\end{array}$} \\
\hline \multicolumn{6}{|c|}{$\begin{array}{l}{ }^{b} p<0.01 ; \text { Group } 3>1 \text { by Tukey's post hoc test, } p=0.024 ; \text { Group } 4>1 \text { by Tukey's post hoc test, } p=0.026 \text {; Group } \\
3>2 \text { by Tukey's post hoc test, } p=0.010 ; \text { Group } 4>2 \text { by Tukey's post hoc test, } p=0.012 ; \text { Group } 1 \text { versus } 2 \text {, } \\
p=1.00 ; \text { Group } 3 \text { versus } 4, p=0.98 \text {. }\end{array}$} \\
\hline \multicolumn{6}{|c|}{$\begin{array}{l}\text { ' } p<0.01 ; \text { Group } 3<1 \text { by Tukey's post hoctest, } p=0.0027 ; \text { Group } 4<1 \text { by Tukey's posthoctest, } p=0.011 ; \text { Group } \\
3<2, p=0.0035 ; \text { Group } 4<2, p=0.011 ; \text { Group } 1 \text { versus } 2, p=0.78 ; \text { Group } 3 \text { versus } 4, p=0.999 .\end{array}$} \\
\hline \multicolumn{6}{|c|}{$\begin{array}{l}{ }^{d} p<0.01 \text {; Group } 3<1 \text { by Tukey's post hoc test, } p<0.0001 \text {; Group } 4<1 \text { by Tukey's post hoc test, } p<0.0001 ; \\
\text { Group } 3<2 \text { by Tukey's post hoc test, } p<0.0001 ; \text { Group } 4<2 \text { by Tukey's post hoc test, } p<0.0001 \text {; Group } 1 \text { versus } \\
2, p=0.53 ; \text { Group } 3 \text { versus } 4, p=0.69 \text {. }\end{array}$} \\
\hline \multicolumn{6}{|c|}{$\begin{array}{l}{ }^{e} p<0.01 ; \text { Group } 3<1 \text { by Tukey's post hoc test, } p<0.0001 ; \text { Group } 4<1 \text { by Tukey's post hoc test, } p<0.0001 \text {; } \\
\text { Group } 3<2 \text { by Tukey's post hoc test, } p<0.0001 ; \text { Group } 4<2 \text { by Tukey's post hoc test, } p<0.0001 ; \text { Group } 1 \text { versus } \\
2, p=0.23 ; \text { Group } 3 \text { versus } 4, p=1 \text {. }\end{array}$} \\
\hline \\
\hline
\end{tabular}

${ }^{f} p<0.01$; Group $3<1$ by Tukey's post hoctest, $p=0.0003$; Group $4<1$ by Tukey's posthoctest, $p=0.013$; Group $3<2, p<0.0001$; Group $4<2, p<0.0001$; Group 1 versus $2, p=0.31$; Group 3 versus $4, p=0.99$.

A

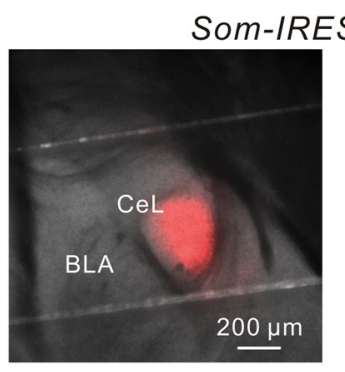

C

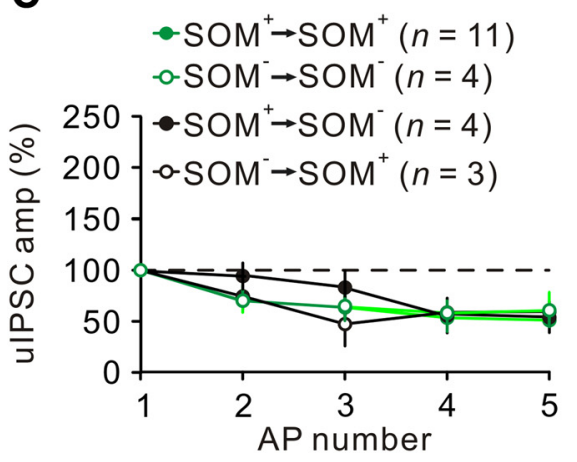

B

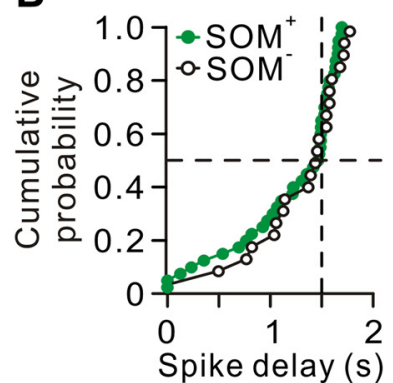

Spike delay (s)

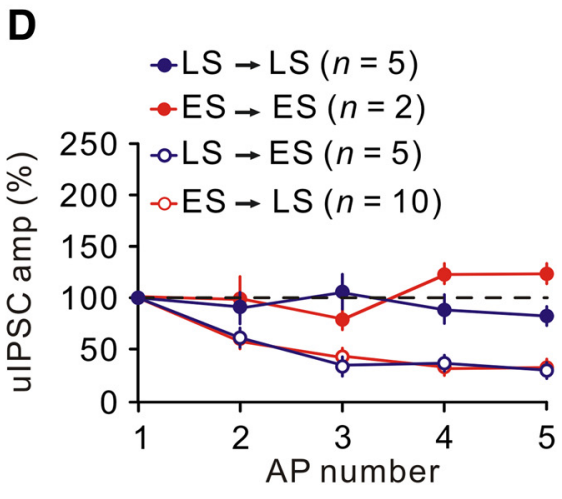

Figure 9. Cell-type-specific transmission was independent of SOM expression in presynaptic and postsynaptic neurons. $A$, Section from the brain of a Som-IRES-cre;Ai14 mouse. Left, Overlay of epifluorescence and IR-DIC images showing CeL with abundant red fluorescence. Right, Enlargement of $\mathrm{CeL} ; \mathrm{SOM}^{+}$cells were visible (red) under epifluorescence. $\boldsymbol{B}$, Cumulative distributions of spike delays from SOM ${ }^{+}$and $\mathrm{SOM}^{-}$cells; the horizontal dashed line indicates the cumulative probability at $1.5 \mathrm{~s}$ spike delay in SOM ${ }^{+}$and SOM ${ }^{-}$groups. C, Left, Average amplitudes normalized to the amplitude of the uIPSC ${ }_{1}$ for each type of connections using SOM as a cell-type marker. $\boldsymbol{D}$, Plot of normalized uIPSC amplitude versus AP number. Neurons in $\boldsymbol{C}$ and $\boldsymbol{D}$ are classified based on their firing patterns. spikes, $n=5 ; p=0.13$, Wilcoxon signed-rank test; Fig. 10F). Because strong synapses were markedly depressed during a $20 \mathrm{~Hz}$ train, firing by a single presynaptic neuron had little effect on subsequent postsynaptic spikes. In contrast, weak synapses led to small reduction in the fifth AP probability (Fig. 10F). Consisthe observations, the initial IPSGs of strong synapses $p<0.01$, Wilcoxon rank-sum test), but rapidly declined during the train (Fig. 10G,H). The distinct synaptic dynamics observed CeL neurons.

\section{Discussion}

In this study, we found that the synapses formed by CeL neurons exhibit distinct types of STP with differential functional consequences. First, $\sim 15 \%$ of CeL neurons form cell-type-dependent functional autapses. Only autapses detected in ES cells contribute to fiknancement of spike-timing precision. Second, CeL neurons form mitual connections wariable connection rates and preferenthe synaptic weight and the dynamics of STP are highly predictable from the identities of both presynaptic and postsynaptic neurons. Finally, we demonstrate that such wiring specificity and synaptic diversity have a great impact

Lack of correlation between intrinsic excitability and the neurochemical marker SOM

$\mathrm{CeL}$ neurons express the cell-subtype-specific neuropeptides SOM and PKC- $\delta$ (Cassell et al., 1986; Haubensak et al., 2010; Li et al., 2013; Penzo et al., 2014). Notably, $\mathrm{SOM}^{+}$and $\mathrm{PKC}-\delta^{+}$neurons are largely nonoverlapping (Li et al., 2013). SOM ${ }^{+}$ neurons display heterogeneous intrinsic excitability (Li et al., 2013). Among $\mathrm{SOM}^{+}$cells, $40 \%$ are LS cells, whereas $60 \%$ are regular spiking (RS) cells (Haubensak et al., 2010; Li et al., 2013), which are similar to the ES cells described in the present study. In contrast, the intrinsic excitability of PKC- $\delta^{+}$neurons is relatively homogeneous. Among PKC- $\delta^{+}$neurons, $86 \%$ are LS cells and $14 \%$ are RS cells (Haubensak et al., 2010). We also identified $\mathrm{SOM}^{+}$neurons, which readily express the red fluorescent protein tdTomato in the Som-IRES-cre;Ai14 mice, and found that $50 \%$ (22 of 44 cells) of $\mathrm{SOM}^{+}$neurons are ES cells (Fig. $9 B$ ), as also shown previously (Li et al., 2013), whereas $55 \%$ (12 of 22 cells) of SOM neurons are LS cells. Expression of the molecular markers SOM and PKC- $\delta$ does not correlate with intrinsic excitability of the CeL neurons.

\section{Possible mechanisms for}

\section{cell-type-specific STP}

Presynaptic, postsynaptic, or other mechanisms could underlie STP (for reviews, see Zucker and Regehr, 2002; Fioravante and Regehr, 2011; Blackman et al., 2013). Several factors that regulate the size 
and dynamics of the presynaptic $\mathrm{Ca}^{2+}$ transient could potentially contribute to presynaptic mechanisms (Kamiya and Zucker, 1994; Koester and Sakmann, 2000; Rozov et al., 2001; Blatow et al., 2003; Koester and Johnston, 2005; Eggermann et al., 2012; Scimemi and Diamond, 2012; Catterall et al., 2013; Liu et al., 2014; Vyleta and Jonas, 2014). STP can also be achieved directly by postsynaptic mechanisms; for example, receptor desensitization (Rozov and Burnashev, 1999), synapse location (Williams and Stuart, 2002), and biophysics of dendritic compartment (Abrahamsson et al., 2012). Notably, postsynaptic molecules or retrograde diffusible messengers from postsynaptic neurons can specifically regulate presynaptic partners and thus contribute to target-cell-specific STP (Sylwestrak and Ghosh, 2012; see review by Blackman et al., 2013). In the present study, the finding in divergent connections reveals target-cell dependency. However, the result of convergent connections strongly indicates that postsynaptic neurons alone do not determine the type of synapse (Gupta et al., 2000; Planert et al., 2010; Liu et al., 2014). A precise match of presynaptic versus postsynaptic cell identities determines STP, suggesting the existence of reciprocal interactions between presynaptic cells and postsynaptic partners (de Wit and Ghosh, 2016).

\section{Nonrandom local circuits in the $\mathrm{CeL}$}

The connectivity between the CeL cells reveals nonuniform selectivity. The CeL cells prefer to form functional synapses with electrically distinct cell classes, whereas electrically identical cells have lower possibility to connect with each other. Our recent study (Liu et al., 2014) demonstrated that the connectivity of non-fast-spiking interneurons onto different target cell types in the hippocampal dentate gyrus is target-cell-type specific, whereas the fast-spiking interneurons innervate the different target cell types with similar probability. The hippocampal hilar local circuit also shows synapse selectivity. Approximately $88 \%$ of the intralamellar connection by hilar mossy cells targeting to the hilar interneurons (Larimer and Strowbridge, 2008). Conversely, the interneurons in the hilus preferentially project to hilar mossy cells (Larimer and Strowbridge, 2008).

A key feature of nonrandom local circuits is cell-type-specific STP. Glutamatergic transmission in the neocortex displays target-cell-specific STP (Markram et al., 1998; Reyes et al., 1998; see review by Blackman et al., 2013). In contrast, presynaptic cell subtype alone is sufficient to determine STP of inhibitory-toinhibitory synapses in local circuits of different brain areas (Geracitano et al., 2007; Ma et al., 2012; Savanthrapadian et al., 2014). to data points, respectively.
B

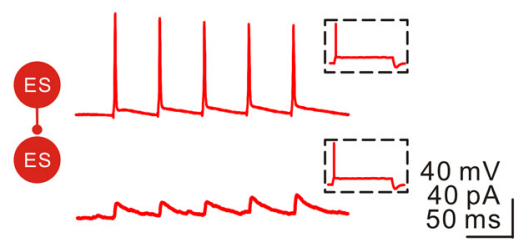

D

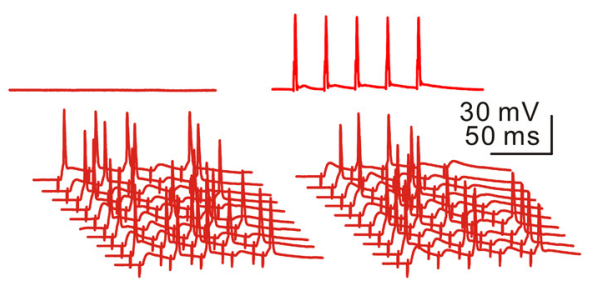

$\mathbf{F}$

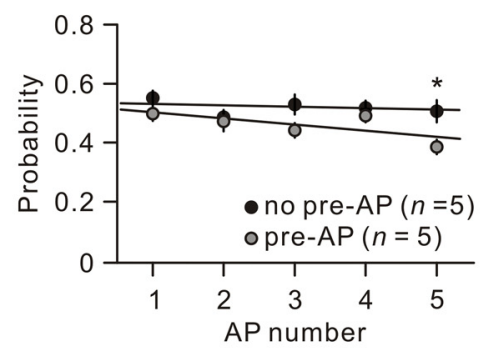

H

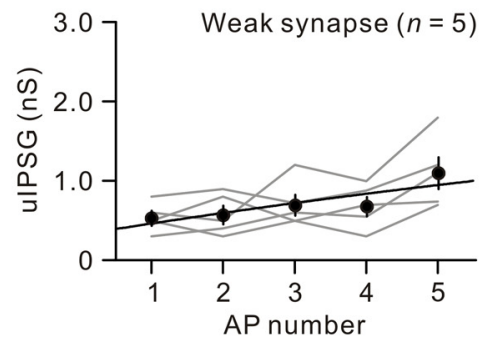

Figure 10. Cell-type-specific STP differentially controlled neuronal output patterns. $A, B$, Example of synaptic transmission between electrically heterogeneous neurons $\mathrm{LS} \rightarrow \mathrm{ES}(\boldsymbol{A})$ or electrically homogeneous neurons $\mathrm{ES} \rightarrow \mathrm{ES}(\boldsymbol{B})$. Representative firing patterns are shown in insets. A train of $5 \mathrm{APs}$ at $20 \mathrm{~Hz}$ was elicited in the presynaptic neurons at $-70 \mathrm{mV}$ in whole-cell currentclamp (top traces); the bottom example traces show the averaged uIPSCs (from 30 single traces; failures included) recorded at a holding potential of $-50 \mathrm{mV}\left(\left[\mathrm{Cl}^{-}\right]_{\mathrm{i}}=7.5 \mathrm{~mm}\right.$ and $\left.E_{\mathrm{Cl}}=-75 \mathrm{mV}\right)$. Traces are color coded by subtype (ES, red; $L S$, blue). C, D, Postsynaptic neurons were held at $-50 \mathrm{mV}$ and depolarized by brief current injections at $20 \mathrm{~Hz}$ (bottom traces). The firing probabilities were kept at $\sim 0.5$ by adjustment of current injection. A presynaptic neuron fired $10 \mathrm{~ms}$ before postsynaptic current injection. $\boldsymbol{E}, \boldsymbol{F}$, Plots showing the comparison of spike probabilities of postsynaptic neurons ( $n=6$ for synapses between electrically heterogeneous neurons; $n=5$ for electrically homogeneous neurons) in the presence or absence of ident presynaptic neuron firing. ${ }^{*} p<0.05 ;{ }^{* * *} p<0.001 . \mathbf{G}, \boldsymbol{H}$, Plots showing uIPSG versus AP number for strong and weak synapses. Gray lines denote individual pairs; black lines and curves represent linear and exponential functions fitted

In this study, the rule governing STP of inhibitory synapses in the CeL is quite different. By recording the divergent and convergent connections, we found that the same GABAergic axon forms distinct types of synapses onto different classes of target neurons, whereas the postsynaptic neuron type alone cannot dictate the type of synapse. Similar to our study, Gupta et al. (2000) also demonstrated that the type of synapse formed is specific to both presynaptic and postsynaptic cell classes, which are distinguished by their anatomical and electrophysiological properties. Our findings support the notion that properly determining neuronal class is therefore critical when investigating synapsespecific STP. 


\section{Relevance of synaptic diversity to the information processing and storage}

The synaptic effect of GABA-mediated inhibitory neurotransmission can sculpt the activity of target neurons. Feedforward inhibition enhances spike-timing precision of cortical neurons by shortening the time window of EPSP summation (Pouille and Scanziani, 2001). In contrast, feedback inhibition scales GABAergic inhibition to local excitatory output, thereby contributing to the generation of rhythmic activities (Mann et al., 2005). Based on microcircuit structures, the CeL comprises both feedforward and feedback inhibitory loops. Indeed, autaptic inhibitory conductance effectively enhances the precision timing of early spikes in a train in ES cells. The degree of jitter in ES cells positively correlates with the autaptic inhibitory conductance. Furthermore, chemical synapses between CeL neurons differentially sculpt the activity pattern in these neurons. Although the specific functional purposes of this arrangement remain unknown, we propose that such combinatorial interactions between two $\mathrm{CeL}$ neurons can maximize synaptic diversity and may be relevant to synaptic modifications during learning and dynamic modulation of neuronal synchrony.

Experimental and theoretical studies suggest that the minimum requirements for neuronal synchrony include mutually connected inhibitory interneurons, a time constant provided by $\mathrm{GABA}_{\mathrm{A}}$ receptors, and sufficient drive to induce spiking in the interneurons (Wang and Rinzel, 1992; Wang and Buzsáki, 1996; Bartos et al., 2001, 2002; Woodruff and Sah, 2007). Hu et al. (2011) demonstrated that different types of inhibitory interneurons in the mouse barrel cortex are capable of coordinating their firing on a submillisecond timescale when paired with either same- or different-subtype interneurons. Furthermore, the degree of neuronal synchrony correlates with inhibitory coupling strength (Bartos et al., 2002; Hu et al., 2011). Therefore, inhibitory coupling via $\mathrm{GABA}_{\mathrm{A}}$ receptors between CeL neurons can contribute to the synchrony of CeL neurons in vivo. In this regard, modulation of CeL neuron activity or synaptic strength by various neuromodulators can fine-tune the synchrony of $\mathrm{CeL}$ neurons and thus control the CeL output (Viviani et al., 2011; Knobloch et al., 2012; Penzo et al., 2014). Overall, the STP between CeL neurons in local circuits is important in the entrainment of their spike output to downstream CeM and other brainstem nuclei. Therefore, further investigation into the functional significance of the specific connectivity pattern formed by CeL cells is critical for understanding the amygdala computation.

\section{References}

Abrahamsson T, Cathala L, Matsui K, Shigemoto R, Digregorio DA (2012) Thin dendrites of cerebellar interneurons confer sublinear synaptic integration and a gradient of short-term plasticity. Neuron 73:1159-1172. CrossRef Medline

Amano T, Unal CT, Paré D (2010) Synaptic correlates of fear extinction in the amygdala. Nat Neurosci 13:489-494. CrossRef Medline

Amano T, Amir A, Goswami S, Paré D (2012) Morphology, PKC $\delta$ expression, and synaptic responsiveness of different types of rat central lateral amygdala neurons. J Neurophysiol 108:3196-3205. CrossRef Medline

Bacci A, Huguenard JR (2006) Enhancement of spike-timing precision by autaptic transmission in neocortical inhibitory interneurons. Neuron 49: 119-130. CrossRef Medline

Bacci A, Huguenard JR, Prince DA (2003) Functional autaptic neurotransmission in fast-spiking interneurons: a novel form of feedback inhibition in the neocortex. J Neurosci 23:859-866. Medline

Bartos M, Vida I, Frotscher M, Geiger JR, Jonas P (2001) Rapid signaling at inhibitory synapses in a dentate gyrus interneuron network. J Neurosci 21:2687-2698. Medline

Bartos M, Vida I, Frotscher M, Meyer A, Monyer H, Geiger JR, Jonas P (2002) Fast synaptic inhibition promotes synchronized gamma oscilla- tions in hippocampal interneuron networks. Proc Natl Acad Sci U S A 99:13222-13227. CrossRef Medline

Bean BP (2007) The action potential in mammalian central neurons. Nat Rev Neurosci 8:451-465. CrossRef Medline

Blackman AV, Abrahamsson T, Costa RP, Lalanne T, Sjöström PJ (2013) Target-cell-specific short-term plasticity in local circuits. Front Synaptic Neurosci 5:11. Medline

Blatow M, Caputi A, Burnashev N, Monyer H, Rozov A (2003) $\mathrm{Ca}^{2+}$ buffer saturation underlies paired pulse facilitation in calbindin-D28kcontaining terminals. Neuron 38:79-88. CrossRef Medline

Böhm C, Peng Y, Maier N, Winterer J, Poulet JF, Geiger JR, Schmitz D. Zucker (2015) Functional diversity of subicular principal cells during hippocampal ripples. J Neurosci 35:13608-13618. CrossRef Medline

Buchanan KA, Blackman AV, Moreau AW, Elgar D, Costa RP, Lalanne T, Tudor Jones AA, Oyrer J, Sjöström PJ (2012) Target-specific expression of presynaptic NMDA receptors in neocortical microcircuits. Neuron 75:451-466. CrossRef Medline

Campanac E, Gasselin C, Baude A, Rama S, Ankri N, Debanne D (2013) Enhanced intrinsic excitability in basket cells maintains excitatory-inhibitory balance in hippocampal circuits. Neuron 77:712-722. CrossRef Medline

Cassell MD, Gray TS, Kiss JZ (1986) Neuronal architecture in the rat central nucleus of the amygdala: a cytological, hodological, and immunocytochemical study. J Comp Neurol 246:478 -499. CrossRef Medline

Cassell MD, Freedman LJ, Shi C (1999) The intrinsic organization of the central extended amygdala. Ann N Y Acad Sci 877:217-241. CrossRef Medline

Catterall WA, Leal K, Nanou E (2013) Calcium channels and short-term synaptic plasticity. J Biol Chem 288:10742-10749. CrossRef Medline

Cauli B, Porter JT, Tsuzuki K, Lambolez B, Rossier J, Quenet B, Audinat E (2000) Classification of fusiform neocortical interneurons based on unsupervised clustering. Proc Natl Acad Sci U S A 97:6144-6149. CrossRef Medline

Chiang PH, Chien TC, Chen CC, Yanagawa Y, Lien CC (2015) ASICdependent LTP at multiple glutamatergic synapses in amygdala network is required for fear memory. Sci Rep 5:10143. CrossRef Medline

Chieng BC, Christie MJ, Osborne PB (2006) Characterization of neurons in the rat central nucleus of the amygdala: cellular physiology, morphology, and opioid sensitivity. J Comp Neurol 497:910-927. CrossRef Medline

Ciocchi S, Herry C, Grenier F, Wolff SB, Letzkus JJ, Vlachos I, Ehrlich I, Sprengel R, Deisseroth K, Stadler MB, Müller C, Lüthi A (2010) Encoding of conditioned fear in central amygdala inhibitory circuits. Nature 468:277-282. CrossRef Medline

Connelly WM, Lees G (2010) Modulation and function of the autaptic connections of layer $\mathrm{V}$ fast spiking interneurons in the rat neocortex. J Physiol 588:2047-2063. CrossRef Medline

Cossart R, Petanjek Z, Dumitriu D, Hirsch JC, Ben-Ari Y, Esclapez M, Bernard C (2006) Interneurons targeting similar layers receive synaptic inputs with similar kinetics. Hippocampus 16:408-420. CrossRef Medline

Debanne D, Guérineau NC, Gähwiler BH, Thompson SM (1996) Pairedpulse facilitation and depression at unitary synapses in rat hippocampus: quantal fluctuation affects subsequent release. J Physiol 491:163-176. CrossRef Medline

de Wit J, Ghosh A (2016) Specification of synaptic connectivity by cell surface interactions. Nat Rev Neurosci 17:4. Medline

Dodson PD, Barker MC, Forsythe ID (2002) Two heteromeric Kv1 potassium channels differentially regulate action potential firing. J Neurosci 22:6953-6961. Medline

Eggermann E, Bucurenciu I, Goswami SP, Jonas P (2012) Nanodomain coupling between $\mathrm{Ca}^{2+}$ channels and sensors of exocytosis at fast mammalian synapses. Nat Rev Neurosci 13:7-21. CrossRef Medline

Ehrlich I, Humeau Y, Grenier F, Ciocchi S, Herry C, Lüthi A (2009) Amygdala inhibitory circuits and the control of fear memory. Neuron 62:757-771. CrossRef Medline

Fioravante D, Regehr WG (2011) Short-term forms of presynaptic plasticity. Curr Opin Neurobiol 21:269-274. CrossRef Medline

Geracitano R, Kaufmann WA, Szabo G, Ferraguti F, Capogna M (2007) Synaptic heterogeneity between mouse paracapsular intercalated neurons of the amygdala. J Physiol 585:117-134. CrossRef Medline

Goldberg EM, Clark BD, Zagha E, Nahmani M, Erisir A, Rudy B (2008) $\mathrm{K}^{+}$ channels at the axon initial segment dampen near-threshold excitability of neocortical fast-spiking GABAergic interneurons. Neuron 58:387-400. CrossRef Medline 
Graves AR, Moore SJ, Bloss EB, Mensh BD, Kath WL, Spruston N (2012) Hippocampal pyramidal neurons comprise two distinct cell types that are countermodulated by metabotropic receptors. Neuron 76:776-789. CrossRef Medline

Gupta A, Wang Y, Markram H (2000) Organizing principles for a diversity of GABAergic interneurons and synapses in the neocortex. Science 287: 273-278. CrossRef Medline

Haubensak W, Kunwar PS, Cai H, Ciocchi S, Wall NR, Ponnusamy R, Biag J, Dong HW, Deisseroth K, Callaway EM, Fanselow MS, Lüthi A, Anderson DJ (2010) Genetic dissection of an amygdala microcircuit that gates conditioned fear. Nature 468:270-276. CrossRef Medline

Hu H, Ma Y, Agmon A (2011) Submillisecond firing synchrony between different subtypes of cortical interneurons connected chemically but not electrically. J Neurosci 31:3351-3361. CrossRef Medline

Jasnow AM, Ressler KJ, Hammack SE, Chhatwal JP, Rainnie DG (2009) Distinct subtypes of cholecystokinin (CCK)-containing interneurons of the basolateral amygdala identified using a CCK promoter-specific lentivirus. J Neurophysiol 101:1494-1506. CrossRef Medline

Johansen JP, Cain CK, Ostroff LE, LeDoux JE (2011) Molecular mechanisms of fear learning and memory. Cell 147:509-524. CrossRef Medline

Kamiya H, Zucker RS (1994) Residual $\mathrm{Ca}^{2+}$ and short-term synaptic plasticity. Nature 371:603-606. CrossRef Medline

Kirchheim F, Tinnes S, Haas CA, Stegen M, Wolfart J (2013) Regulation of action potential delays via voltage-gated potassium Kv1.1 channels in dentate granule cells during hippocampal epilepsy. Front Cell Neurosci 7:248. Medline

Knobloch HS, Charlet A, Hoffmann LC, Eliava M, Khrulev S, Cetin AH, Osten P, Schwarz MK, Seeburg PH, Stoop R, Grinevich V (2012) Evoked axonal oxytocin release in the central amygdala attenuates fear response. Neuron 73:553-566. CrossRef Medline

Koester HJ, Johnston D (2005) Target cell-dependent normalization of transmitter release at neocortical synapses. Science 308:863-866. CrossRef Medline

Koester HJ, Sakmann B (2000) Calcium dynamics associated with action potentials in single nerve terminals of pyramidal cells in layer $2 / 3$ of the young rat neocortex. J Physiol 529:625-646. CrossRef Medline

Larimer P, Strowbridge BW (2008) Nonrandom local circuits in the dentate gyrus. J Neurosci 28:12212-12223. CrossRef Medline

LeDoux J (2007) The amygdala. Curr Biol 17:R868-R874. CrossRef Medline

Li H, Penzo MA, Taniguchi H, Kopec CD, Huang ZJ, Li B (2013) Experience-dependent modification of a central amygdala fear circuit. Nat Neurosci 16:332-339. CrossRef Medline

Lien CC, Jonas P (2003) Kv3 potassium conductance is necessary and kinetically optimized for high-frequency action potential generation in hippocampal interneurons. J Neurosci 23:2058-2068. Medline

Liu YC, Cheng JK, Lien CC (2014) Rapid dynamic changes of dendritic inhibition in the dentate gyrus by presynaptic activity patterns. J Neurosci 34:1344-1357. CrossRef Medline

Lopez de Armentia M, Sah P (2004) Firing properties and connectivity of neurons in the rat lateral central nucleus of the amygdala. J Neurophysiol 92:1285-1294. CrossRef Medline

Ma Y, Hu H, Agmon A (2012) Short-term plasticity of unitary inhibitoryto-inhibitory synapses depends on the presynaptic interneuron subtype. J Neurosci 32:983-988. CrossRef Medline

Madisen L, Zwingman TA, Sunkin SM, Oh SW, Zariwala HA, Gu H, Ng LL, Palmiter RD, Hawrylycz MJ, Jones AR, Lein ES, Zeng H (2010) A robust and high-throughput Cre reporting and characterization system for the whole mouse brain. Nat Neurosci 13:133-140. CrossRef Medline

Mann EO, Suckling JM, Hajos N, Greenfield SA, Paulsen O (2005) Perisomatic feedback inhibition underlies cholinergically induced fast network oscillations in the rat hippocampus in vitro. Neuron 45:105-117. CrossRef Medline

Maren S (2001) Neurobiology of Pavlovian fear conditioning. Annu Rev Neurosci 24:897-931. CrossRef Medline

Markram H, Wang Y, Tsodyks M (1998) Differential signaling via the same axon of neocortical pyramidal neurons. Proc Natl Acad Sci U S A 95: 5323-5328. CrossRef Medline

Martina M, Schultz JH, Ehmke H, Monyer H, Jonas P (1998) Functional and molecular differences between voltage-gated $\mathrm{K}^{+}$channels of fastspiking interneurons and pyramidal neurons of rat hippocampus. J Neurosci 18:8111-8125. Medline
Martina M, Royer S, Paré D (1999) Physiological properties of central medial and central lateral amygdala neurons. J Neurophysiol 82:1843-1854. Medline

Mathews PJ, Jercog PE, Rinzel J, Scott LL, Golding NL (2010) Control of submillisecond synaptic timing in binaural coincidence detectors by Kv1 channels. Nat Neurosci 13:601-609. CrossRef Medline

Myatt DR, Hadlington T, Ascoli GA, Nasuto SJ (2012) Neuromantic-from semi-manual to semi-automatic reconstruction of neuron morphology. Front Neuroinform 6:4. Medline

Pare D, Duvarci S (2012) Amygdala microcircuits mediating fear expression and extinction. Curr Opin Neurobiol 22:717-723. CrossRef Medline

Paré D, Quirk GJ, Ledoux JE (2004) New vistas on amygdala networks in conditioned fear. J Neurophysiol 92:1-9. CrossRef Medline

Penzo MA, Robert V, Li B (2014) Fear conditioning potentiates synaptic transmission onto long-range projection neurons in the lateral subdivision of central amygdala. J Neurosci 34:2432-2437. CrossRef Medline

Pitkänen A, Savander V, LeDoux JE (1997) Organization of intraamygdaloid circuitries in the rat: an emerging framework for understanding functions of the amygdala. Trends Neurosci 20:517-523. CrossRef Medline

Planert H, Szydlowski SN, Hjorth JJ, Grillner S, Silberberg G (2010) Dynamics of synaptic transmission between fast-spiking interneurons and striatal projection neurons of the direct and indirect pathways. J Neurosci 30:3499-3507. CrossRef Medline

Pouille F, Scanziani M (2001) Enforcement of temporal fidelity in pyramidal cells by somatic feed-forward inhibition. Science 293:1159-1163. CrossRef Medline

Ramikie TS, Nyilas R, Bluett RJ, Gamble-George JC, Hartley ND, Mackie K, Watanabe M, Katona I, Patel S (2014) Multiple mechanistically distinct modes of endocannabinoid mobilization at central amygdala glutamatergic synapses. Neuron 81:1111-1125. CrossRef Medline

Reyes A, Lujan R, Rozov A, Burnashev N, Somogyi P, Sakmann B (1998) Target-cell-specific facilitation and depression in neocortical circuits. Nat Neurosci 1:279-285. CrossRef Medline

Roberto M, Cruz M, Bajo M, Siggins GR, Parsons LH, Schweitzer P (2010) The endocannabinoid system tonically regulates inhibitory transmission and depresses the effect of ethanol in central amygdala. Neuropsychopharmacology 35:1962-1972. CrossRef Medline

Rozov A, Burnashev N (1999) Polyamine-dependent facilitation of postsynaptic AMPA receptors counteracts paired-pulse depression. Nature 401:594-598. CrossRef Medline

Rozov A, Burnashev N, Sakmann B, Neher E (2001) Transmitter release modulation by intracellular $\mathrm{Ca}^{2+}$ buffers in facilitating and depressing nerve terminals of pyramidal cells in layer $2 / 3$ of the rat neocortex indicates a target cell-specific difference in presynaptic calcium dynamics. J Physiol 531:807-826. CrossRef Medline

Savanthrapadian S, Meyer T, Elgueta C, Booker SA, Vida I, Bartos M (2014) Synaptic properties of SOM- and CCK-expressing cells in dentate gyrus interneuron networks. J Neurosci 34:8197-8209. CrossRef Medline

Scimemi A, Diamond JS (2012) The number and organization of $\mathrm{Ca}^{2+}$ channels in the active zone shapes neurotransmitter release from Schaffer collateral synapses. J Neurosci 32:18157-18176. CrossRef Medline

Sholl DA (1953) Dendritic organization in the neurons of the visual and motor cortices of the cat. J Anat 87:387-406. Medline

Sigurdsson T, Doyère V, Cain CK, LeDoux JE (2007) Long-term potentiation in the amygdala: a cellular mechanism of fear learning and memory. Neuropharmacology 52:215-227. CrossRef Medline

Sosulina L, Graebenitz S, Pape HC (2010) GABAergic interneurons in the mouse lateral amygdala: a classification study. J Neurophysiol 104:617626. CrossRef Medline

Spearman C (1904) The proof and measurement of association between two things. Am J Psychol 15:72-101. CrossRef

Storm JF (1988) Temporal integration by a slowly inactivating $\mathrm{K}^{+}$current in hippocampal neurons. Nature 336:379-381. CrossRef Medline

Sylwestrak EL, Ghosh A (2012) Elfn1 regulates target-specific release probability at CA1-interneuron synapses. Science 338:536-540. CrossRef Medline

Tamás G, Buhl EH, Somogyi P (1997) Massive autaptic self-innervation of GABAergic neurons in cat visual cortex. J Neurosci 17:6352-6364. Medline 
Taniguchi H, He M, Wu P, Kim S, Paik R, Sugino K, Kvitsiani D, Fu Y, Lu J, Lin Y, Miyoshi G, Shima Y, Fishell G, Nelson SB, Huang ZJ (2011) A resource of Cre driver lines for genetic targeting of GABAergic neurons in cerebral cortex. Neuron 71:995-1013. CrossRef Medline

Viviani D, Charlet A, van den Burg E, Robinet C, Hurni N, Abatis M, Magara F, Stoop R (2011) Oxytocin selectively gates fear responses through distinct outputs from the central amygdala. Science 333:104-107. CrossRef Medline

Vyleta NP, Jonas P (2014) Loose coupling between $\mathrm{Ca}^{2+}$ channels and release sensors at a plastic hippocampal synapse. Science 343:665-670. CrossRef Medline

Walker GA (2002) Common statistical methods for clinical research with $\mathrm{SAS}^{\circledR}$ examples, Ed 2. Cary, NC: SAS Institute.

Wang XJ, Buzsáki G (1996) Gamma oscillation by synaptic inhibition in a hippocampal interneuronal network model. J Neurosci 16:6402-6413. Medline

Wang XJ, Rinzel J (1992) Alternating and synchronous rhythms in reciprocally inhibitory model neurons. Neural Comput 4:84-97. CrossRef
Ward JH (1963) Hierarchical grouping to optimize an objective function. J Am Stat Assoc 58:236-244. CrossRef

Wilensky AE, Schafe GE, Kristensen MP, LeDoux JE (2006) Rethinking the fear circuit: the central nucleus of the amygdala is required for the acquisition, consolidation, and expression of Pavlovian fear conditioning. J Neurosci 26:12387-12396. CrossRef Medline

Williams SR, Stuart GJ (2002) Dependence of EPSP efficacy on synapse location in neocortical pyramidal neurons. Science 295:1907-1910. CrossRef Medline

Woodruff AR, Sah P (2007) Inhibition and synchronization of basal amygdala principal neuron spiking by parvalbumin-positive interneurons. J Neurophysiol 98:2956-2961. CrossRef Medline

Zimmer A, Zimmer AM, Hohmann AG, Herkenham M, Bonner TI (1999) Increased mortality, hypoactivity, and hypoalgesia in cannabinoid CB1 receptor knockout mice. Proc Natl Acad Sci U S A 96:5780-5785. CrossRef Medline

Zucker RS, Regehr WG (2002) Short-term synaptic plasticity. Annu Rev Physiol 64:355-405. CrossRef Medline 